\title{
PODOBIEŃSTWA I RÓŻNICE W INTERPRETACJI SZKIELETU JAKO POSTACI NADPRZYRODZONEJ W CHRZEŚCIJAŃSKIEJ EUROPIE ZACHODNIEJ ORAZ W JAPONII
}

\author{
AGNIESZKA PĄCZKOWSKA ${ }^{1}$ \\ (Uniwersytet im. Adama Mickiewicza w Poznaniu)
}

Słowa kluczowe: szkielet - śmierć - Japonia - Europa

Key words: skeleton - death - Japan - Europe

\begin{abstract}
Abstrakt: Agnieszka Pączkowska. PODOBIEŃSTWA I RÓŻNICE W INTERPRETACJI SZKIELETU JAKO POSTACI NADPRZYRODZONEJ W CHRZEŚCIJAŃSKIEJ EUROPIE ZACHODNIEJ ORAZ W JAPONII. PORÓWNANIA 18, 2016. T. XVIII. S. 61-90. ISSN 1733-165X. Ludzka czaszka oraz szkielet są symbolami, które jednoznacznie kojarzą się ze śmiercią i można by je uznać za uniwersalne, jednakże ich prawdziwe znaczenie może się różnić w zależności od prądów kulturalno-religijnych, które je ukształtowały. W cywilizacji chrześcijańskiej zachodniej Europy i w Japonii suche ludzkie kości nie tylko leżały w grobie, ale poruszały się w wyobraźni ludzi i w sztuce. W europejskiej interpretacji szkielet stał się konkretną osobą, personifikacją śmierci. Natomiast w japońskiej kulturze przedstawiał on mściwego ducha dokonującego zemsty na wybranych osobach. Podobieństwa i różnice w znaczeniu symbolu szkieletu zanalizowano w oparciu o źródła historyczno-literackie i artystyczne.
\end{abstract}

Abstract: Agnieszka Pączkowska. THE ANALYSIS OF SIMILARITIES AND DIFFERENCES IN THE INTERPRETATIONS OF THE SKELETON AS A SUPERNATURAL BEING IN CHRISTIAN WESTERN EUROPE AND JAPAN. COMPARISONS 18, 2016. Vol. XVIII. P. 61-90. ISSN 1733-165X. The human skull and the skeleton are symbols unmistakably associated with death; one would even call them 'universal'. However, their true meaning may differ depending on cultural and religious trends that shaped them. In Christian Western Europe and Japan, the dry naked human bones were not to lie lifelessly in graves; people imagined them to move and dance. The Europeans interpreted the skeleton as an actual person. It became a personification of

${ }^{1}$ E-mail Address: apaczkowska@amu.edu.pl 
death, the Death. On the other hand, the Japanese treated the skeleton as a graphic representation of a vengeful soul that came back to the world of living to execute revenge on their enemies. The analysis of similarities and differences in the interpretations of the skeleton as a symbol related to death are based on historic, literary and artistic sources.

\section{Wstęp}

Ludzka czaszka oraz szkielet są symbolami, które jednoznacznie kojarzą się ze śmiercią i można by je uznać za uniwersalne, jednakże ich prawdziwe znaczenie może się różnić w zależności od prądów kulturalno-religijnych, które je ukształtowały. Niniejszy artykuł jest próbą zinterpretowania i porównania szkieletu jako postaci nadprzyrodzonej w chrześcijańskiej Europie Zachodniej oraz Japonii.

Chrześcijańska teologia definiowała śmierć jako rozdzielenie duszy od ciała, które miały połączyć się na nowo podczas powtórnego przyjścia Chrystusa. Choć Katharine Park ${ }^{2}$ twierdzi, że bardziej skupiano się na losie duszy w zaświatach niż ciała na ziemi, trudno nie zgodzić się z Paulem Binskim³, że fizyczna śmierć zawsze stanowiła rdzeń chrześcijaństwa. Jako przykłady podaje on często podejmowane tematy ukrzyżowania i zmartwychwstania Jezusa oraz śmierci męczeńskiej. Ludzkie zwłoki będące jedynym namacalnym dowodem na czyjąś śmierć, stały się pierwszym przedstawieniem śmierci. Wyobrażenie to stało się bardzo popularne i jego ślady można znaleźć w wielu krajach nie tylko Europy Zachodniej, ale także w różnorodnych kręgach kulturowych w północnej i wschodniej części kontynentu (Cheney 33). Ostatecznie, w wyniku długiego procesu oswajania się ze śmiercią przedstawienia przyjęły formę $\mathrm{w}$ pełni ukształtowanej postaci, wyobrażanej jako żywy szkielet - Śmierć ${ }^{\text {. }}$

W Japonii śmierć traktowano ze strachem i niezrozumieniem. Według pierwszych źródeł pisanych (VIII wiek), moment odejścia ze świata doczesnego był niejasny, a zaświaty wyobrażano sobie jako dalekie, nieokreślone miejsce $\mathrm{w}$ chmurach $^{5}$. Żywi żyli razem z duchami zmarłych przodków, ale w odosobnieniu od ich

${ }^{2}$ K. Park. "Birth and Death". A Cultural History of the Human Body in the Medieval Age. Red. L. Kalof. Oxford: Berg, 2010. S. 17-38.

${ }^{3}$ P. Binski. Medieval Death. Ritual and Representation. London: British Museum Press, 1996.

$4 \mathrm{~W}$ niniejszym artykule śmierć jest przedstawiana jako postać żeńska. Problem płci w personifikacji śmierci został pominięty. Więcej w K.S. Guthke. The Gender of Death. A Cultural History in Art and Literature. Cambridge: Cambridge University Press, 1999. Słowo śmierć zapisywane wielką literą wskazuje na personifikację.

${ }^{5} \mathrm{~W}$ pierwszych źródłach historycznych zaświaty są opisywane jako miejsce ciemne i przerażające (patrz przypis 34). Z kolei w pierwszej antologii poezji Manyōshū (Zbiór dziesięć tysięcy liści, 780), poeci podejmowali temat śmierci w sposób pośredni, opisując ją jako przejście do krainy położonej 
zwłok, które traktowano jako źródło nieczystości. Przekonanie to znalazło swoje odzwierciedlenie między innymi w prawie i medycynie. $Z$ kolei, według zyskującego na popularności buddyzmu ${ }^{6}$, nie tylko martwe, ale także żywe ciało mogło być nieczyste. $\mathrm{W}$ związku $\mathrm{z}$ tym szkielety przedstawiano artystycznie jako leżące $\mathrm{w}$ bezruchu szczątki, mające przypominać ulotność ziemskiego świata. Zwłoki wzbudzały negatywne skojarzenia, ale pomimo to w starożytnej i późniejszej literaturze oraz $\mathrm{w}$ dziewiętnastowiecznej sztuce drzeworytów duchy zmarłych, zarówno o dobrych jak i złych intencjach, utożsamiano ze szkieletem lub jego czaszką.

Chociaż ludzkie szczątki symbolizowały śmierć zarówno w chrześcijańskiej Europie Zachodniej, jak i Japonii, niejasne pozostają interpretacja i znaczenie ruchomego szkieletu jako bytu nadprzyrodzonego. Co spowodowało, że zaczął się ruszać? Jaką ideę chciano przekazać grzechoczącymi kośćmi?

Odpowiedzi na te pytania mogą różnić się nie tylko w zależności od dziedziny, ale także ze względu na wewnętrzne podziały w obrębie danej dyscypliny. $Z$ tego powodu, aby ustrzec się przed zbyt wieloma, a nawet sprzecznymi wyjaśnieniami skupiono się na popularnych wierzeniach ludowych ${ }^{7}$ konkretnych okresów historycznych. Opierają się one na interpretacjach badaczy, duchownych, pisarzy czy zwykłych ludzi, na które wpłynęły obecnie rozdzielone dziedziny, jak religia, filozofia czy medycyna. Jako materiał źródłowy wykorzystam znane dzieła sztuki sakralnej i świeckiej (kościelne murale, groby, ilustrowane zwoje, drzeworyty). Odniesiono się także do literatury (kronik historycznych, poezji sakralnej, opowie-

daleko za górami lub wśród chmur (Ebersole 81). Może być to odniesienie do przekonań traktujących góry jako miejsce mistyczne, w którym świat ludzi styka się ze światem istot nadprzyrodzonych (Hori 151). Obraz zaświatów ewoluował wraz z przyjęciem buddyzmu, m.in. w zbiorze opowieści dydaktycznych i anegdod ludowych Konjaku monogatarishū (Opowieści z dawnych czasów, XI wiek), który zawiera opowiadania nawet z VII wieku, można zauważyć silny wpływ symboliki buddyjskiej w ukazywaniu śmierci i tematyki zaświatów, np. w szczegółowych opisach krain niebiańskich i piekielnych przedstawianych przez dusze, które odesłano z powrotem do świata żywych. Niemniej w źródłach zawierających elementy mitologiczne, do których udało się dotrzeć autorowi, temat śmierci zdawał się być opisany ogólnikowo, jeśli nie mgliście.

${ }^{6}$ Choć oficjalnie buddyzm pojawił się $\mathrm{w}$ Japonii $\mathrm{w}$ VI wieku, niektóre elementy buddyjskie (np. lustra) były znane już w II wieku (Kanert 123). Oznacza to, że prawdopodobnie proces mieszania się wierzeń rdzennych z ideami zaimportowanymi z kontynentu rozpoczął się na Archipelagu Japońskim kilkaset lat przed oficjalną datą przyjęcia buddyzmu. Może to poddawać pod wątpliwość, czy praktyki religijne uznawane za rodzime są faktycznie rodzime.

Pozycja buddyzmu na dworze cesarskim umacniała się stopniowo od VI wieku. W początkowych wiekach okresu Heian (794-1185) był on bardzo popularny wśród warstw arystokratycznych i duchownych, z kolei w końcowych wiekach zaczął się powoli rozprzestrzeniać wśród reszty społeczeństwa.

${ }^{7}$ Za popularne wierzenia ludowe uznano powszechnie dostępne i/lub zaakceptowane przekonania, które przekraczają granicę klasyfikacji (tzn. nie są wytworem tylko jednej konkretnej dziedziny, ale ich wzajemnego wpływu, np. medyczno-filozoficzne) lub są wynikiem nakładania się dwóch różnych koncepcji. 
ści sakralnych i folklorystycznych, przełomowych traktatów medycznych). Wybrane z nich fragmenty podejmują temat śmierci fizycznej, które z czasem doprowadziły do powstania figury ruchomego szkieletu jako bytu nadprzyrodzonego. Część artykułu odnosząca się do Europy dotyczy głównie procesu personifikacji śmierci jako indywidualnej osoby przedstawianej w formie kościotrupa. Skupiono się głównie na motywach trzech żywych i trzech umarłych, grobowcach transi oraz danse macabre. "Japońska część" artykułu traktuje natomiast o koncepcji nieczystości śmierci oraz jej wpływu na percepcję ludzkich zwłok. Poglądy te porównam z najbardziej znaczącymi drzeworytami przedstawiającymi szkielety.

Celem analizy jest pogłębienie zrozumienia figury szkieletu jako alegorii śmierci, a także podkreślenie różnicy pomiędzy osobą Śmierci i zjawiskiem śmierci zakorzenionych $w$ dwóch różnych kręgach kulturowych. Obszar kulturowy ma ogromny wpływ na interpretację symboli, nawet wtedy, gdy z perspektywy kultury globalnej wydają się one oczywiste i jednoznaczne.

\section{Śmierć oswojona8}

W średniowieczu sposób, w jaki postrzegano ludzką egzystencję wynikał z mieszania się idei chrześcijańskich z popularnymi wierzeniami ludowymi. W ideologii Kościoła proces umierania rozróżniono od stanu bycia umarłym. Rozgraniczenie to było wynikiem teologicznej koncepcji, mówiącej o rozdzieleniu ciała i duszy. Innymi słowy, śmierć następowała w chwili, gdy niematerialna dusza opuszczała materialne ciało (Binski 70). Nie potępiano aspektu fizycznego, wręcz przeciwnie - w niektórych przy padkach wręcz go gloryfikowano. Za śmierć idealną uważano śmierć męczennika, którego zwłoki traktowano jako źródło nadprzyrodzonej mocy ${ }^{9}$. Wierzono, że jeżeli zwykły człowiek zostanie pochowany w pobliżu grobu męczennika, to, tak jak on, zostanie zbawiony ${ }^{10}$. Duchowni głosili także kazania o kruchości doczesnego świata i nieuniknionej śmierci.

$\mathrm{W}$ ten sposób starali się zachęcić wiernych do porzucenia ziemskich dóbr i skromnego życia. Chcąc poprzez strach przekonać słuchaczy do swoich racji, napominano ich nazbyt znanym zawołaniem memento mori, które podkreślano rekwizytami, na przykład prawdziwą ludzką czaszką (Clark 94). W tym okresie umieranie rozumiano jako powolny proces, do którego należało uczynić odpowiednie przygotowania, zanim śmierć ostatecznie nawiedzi umierającego. Było to

\footnotetext{
8 Określenie zapożyczone z P. Ariès. Człowiek i śmierć. Warszawa: Aletheia, 2011. S. 19.

${ }^{9}$ Między innymi w ten sposób odrzucono starożytne tabu ciążące na zwłokach i śmierci (Ariès 2011: 49).

${ }^{10}$ Dodatkowo posiadanie takich relikwii dodawało prestiżu danemu kościołowi (Ariès 2011: 43-46).
} 
możliwe dzięki temu, że każdy bliski śmierci człowiek miał przeczuwać jej nadejście. Kościół uznawał śmierć za dobrą, gdy konający zakończył swoje ziemskie sprawy, pogodził się z tymi, których skrzywdził, złożył pieniężną ofiarę na kościół, wyspowiadał się, przyjął komunię i w spokoju, pełen akceptacji, po raz ostatni zamknął oczy (Park 28). Umierający nie pozostawał samotny w ostatnich chwilach życia. Znajdował się w centrum uwagi, otoczony przez krewnych (Ariès 2011: 32). Następnie zwłoki składano w grobie i wierzono, że zmarły w stanie snu oczekuje na zbawienie (Ariès 2011: 36). Tymczasem w wierzeniach ludowych metaforą życia i śmierci była lampa oliwna. Proces starzenia się porównywano do wysychania oliwy i nieuchronnego ochłodzenia. Życie nie kończyło się jednak w momencie śmierci, ale trwało dalej podczas rozkładu zwłok, póki nie zmieniły się one w suche kości (Park 33-34). Wierzono także, że siła życiowa nie ulatniała się, ale pozostawała w ciele, które mogło się poruszać. Dusza mogła pozostać i błąkać się w pobliżu, zwłaszcza gdy kogoś spotkała nagła, brutalna śmierć (McTavish 29). Ze względu na to, że wizyta śmierci miała być zapowiedziana, nagłą śmierć uważano za niegodną i straszną. Podobnym piętnem naznaczono śmierć bez świadków czy ofiary morderstw (Ariès 2011: 24-25).

Kościół bardzo ostrożnie próbował walczyć z tymi wierzeniami. Głoszono, że martwe ciała animowały tylko złe demony. Innym sposobem rozwiązania tego problemu było wprowadzenie $\mathrm{w}$ dwunastym wieku koncepcji czyśćca'11. Miało to zachęcić wiernych do odmawiania modlitw za zmarłych i składania ofiar pieniężnych w zamian za rytuały skracające czas zmarłego w czyśćcu. Ich działanie uważano za skuteczne nawet na długo po czyjejś śmierci ${ }^{12}$. Co więcej, między XII a XIII wiekiem pojawiła się idea Sądu Ostatecznego, która rozwinęła się w dramat rozgrywający się w chwili śmierci człowieka.

Na szali ważono żywot zmarłego i na tej podstawie decydowano o jego metafizycznym przeznaczeniu (Ariès 2011: 111-113). Mimo podjętych prób duchowni nie mogli rywalizować z przekonaniem ludu, że we właściwych okolicznościach ciała mogły wstać z grobu i chodzić między żywymi (Park 34).

\section{Fizyczna śmierć w legendzie o trzech żywych i trzech umarłych, transi oraz danse macabre}

Przekonanie o śmierci jako towarzyszce życia umocniło się wraz z wybuchem epidemii Czarnej Śmierci w XIV wieku13. W obliczu katastrofy i ciągłego

\footnotetext{
11 Upowszechnił się ok. II poł. XVII wieku (Ariès 2011: 118).

$12 \mathrm{Z}$ biegiem czasu na tej podstawie uformowała się długotrwała więź pomiędzy żywymi i umarłymi (McTavish 29).

${ }^{13}$ Według najnowszych badań przyczyną wybuchu epidemii dżumy była przenoszona przez muchy bakteria żerująca na gryzoniach. Prawdopodobnie rozprzestrzeniła się przez handel morski
} 
kontaktu ze zwłokami, obecność śmierci była odczuwalna bardziej niż kiedykolwiek. Katastroficzną atmosferę tego okresu można odczuć w zapiskach kronikarza ze Sieny, Angelo di Tura (XIV wiek).

Wydawało się, że prawie wszyscy otępieli z rozpaczy i bezsilności. Ludzki język nie jest w stanie wyrazić okrutnej prawdy. [...] A tak wielu umarło, że wszyscy uwierzyli, że nadszedł koniec świata (Gottfried 45).

Przed plagą dżumy istniało wiele interpretacji śmierci14, ale samo to doświadczenie mogło wpłynąć na popularyzację niektórych z nich. Część można by nawet zaliczyć do tak zwanego nurtu głównego, gdyż stały się popularne w różnych regionach Europy i zostały włączone w lokalne tradycje. Choć pojawiły się one oddzielnie, koegzystowały w ludzkiej wyobraźni. Były to: legenda o trzech żywych i trzech umarłych, groby transi i najbardziej godny uwagi danse macabre taniec śmierci). Motywy te akcentowały fizyczny aspekt śmierci, przez co można uznać je za oznaki fascynacji rozkładającym się ciałem, wyrażanej w efekcie makabry. Najstarszy z motywów, czyli legenda o trzech żywych i trzech umarłych, był popularny we Francji i w Niemczech, ale jego ślady znajdujemy też w Anglii, Włoszech i Hiszpanii. Chociaż istniało wiele wersji tej historii, jej źródła sięgają trzynastowiecznych utworów poetyckich ${ }^{15}$ o trzech młodych mężczyznach spotykających trzy ożywione trupy. Umarli uczą żywych o ulotnej naturze życia i konieczności skruchy za swoje czyny. $W$ czternastowiecznych miniaturach, pochodzących ze wspomnianych krajów, są zwykle zobrazowani jako trzy ciała w trzech różnych stadiach rozkładu, z których ostatni bardzo przypomina szkielet. Warto zauważyć, że zwłoki są głównymi postaciami i są całkowicie widoczne, co daje wrażenie podjęcia tematu śmierci $\mathrm{w}$ bezpośredni sposób. Przesłaniem tej metafory mogło być „kim jesteśmy, wy będziecie” (Byrne 24). To definiuje więź między żywymi i umarłymi prezentując ich jako sobowtóry, co najlepiej widać w miniaturze z francuskiego wydania Livre d'heures ${ }^{16}$ (1480-90): trzema żywymi są papież, cesarz i król, stojący przed swoimi zwłokami. Każda para ma na głowie odpowiadające funkcji identyczne korony.

z Chin do Europy. Plaga była najgroźniejsza w 1348, 1360, 1373 i 1382 roku. Szacuje się, że na terytoriach, gdzie pojawiła się Czarna Śmierć zginęło ok. 1/3 - 2/3 populacji danych obszarów (Binski 126).

${ }^{14} \mathrm{~W}$ tekście ograniczono się do motywów związanych z interpretacją śmierci, które bezpośrednio nawiązują do jej fizycznego aspektu.

${ }^{15}$ Dokładne źródło pochodzenia utworów pozostaje tajemnicą, gdyż znaleziono wiele wersji wierszy w różnych europejskich językach.

${ }^{16}$ Księgi godzin to bogato zdobione, ilustrowane zbiory religijnych tekstów, modlitw, psalmów, etc. Były one skróconą wersją psałterzy oraz brewiarzy. Pojawiły się w połowie XIII wieku. Więcej w V. Reinburg. Frenchbooks of hours: making an archive of prayer, c. 1400-1600. Cambridge: Cambridge University Press, 2012. 
Koncepcję dublerów kontynuowano w grobach transi, które pojawiły się głównie w północnej Europie, ale także we Francji (Gertsman 29). Był to podwójny nagrobek, który składał się z górnej i dolnej części. Na górze przedstawiano wyobrażenie zmarłego pogrążonego we śnie, a pod nim jego rozkładające się ciało. Jako przykład można podać grobowce Richarda Fleminga w Lincoln Cathedral lub Henry'ego Chichele'a w Canterbury Cathedral. Tutaj również uwaga zostaje skupiona na fizycznym aspekcie śmierci, z tą różnicą, że ulegający rozkładowi zmarły został zestawiony z koncepcją oczekiwania na zbawienie we śnie. Motyw transi dobrze wpisywał się w kaznodziejską retorykę Kościoła o kruchości i ulotności ludzkiego życia (Cheney 182). W niektórych przypadkach górna część grobowca przedstawiała śpiącego $\mathrm{z}$ symbolami ziemskiego statusu, natomiast dolna była pozbawiona wszelkich ozdób. Można stwierdzić, że postać transi była krokiem naprzód $\mathrm{w}$ przedstawianiu ludzkich zwłok jako reprezentacji śmierci równej dla wszystkich żywych.

Kolejnym motywem, który przyczynił się do personifikacji śmierci był, najbardziej popularny z dotąd przedstawionych, taniec śmierci. Jako fraza danse macabre pojawił się po raz pierwszy w literaturze, w poemacie Jeana Le Fèvre (1325-1380) Respit de la mort ${ }^{17}$ (Wytchnienie od śmierci, 1376), choć źródła samego motywu pozostają niewyjaśnione ${ }^{18} \mathrm{z}$ powodu niewielkiej liczby zachowanych murali (Byrne 101). Prawdę o naturze życia i śmierci ${ }^{19}$ próbowano ukazać w korowodzie reprezentantów wszystkich klas społecznych, tańczących z własnym martwym sobowtórem. Ze względu na to, że zachowane do dziś murale zdobią ściany kościołów, a na początku procesji często pojawia się postać kaznodziei, twierdzi się, że był to motyw silnie związany z Kościołem katolickim, który prawdopodobnie rozprzestrzenił tę koncepcję poprzez kazania na inne regiony Europy. Ślady danse macabre

17 Autor napisał poemat jako pokutę za popełnione grzechy, gdy niespodziewanie wyzdrowiał po ciężkiej chorobie. W utworze Le Fèvre prosi Boga o odroczenie swojego końca i przytacza rozmowę z dwójką przyjaciół o możliwości wytchnienia od śmierci. W zakończeniu odwołuje się do związku pomiędzy makro i mikrokosmosem oraz do alegorii drabiny Jakuba. Więcej w L. Burke. The book of gladness. Le livre de Leesce: a 14th century defense of women, in English and French. Jefferson, North Carolina: McFarland \& Company, Inc., Publishers, 2013.

${ }^{18}$ Istnieje kilka koncepcji dotyczących pochodzenia dance macabre, zwłaszcza z perspektywy postrzegania tańca przez Kościól, np. historia o tancerzach z Kölbigk w diecezji Magdeburskiej z Nürnberger Chronik (1493). Jednak nie ma wzmianek o tym jakoby taniec śmierci był inspirowany nadprzyrodzonymi zdarzeniami jak zmarli wstający z grobów i tańczący na cmentarzu, czy faktycznymi zgromadzeniami przedstawicieli wszystkich klas społecznych w celu odtworzenia motywu (Clark 106-107).

${ }^{19} \mathrm{~W}$ średniowiecznych wierzeniach ludowych wierzono, że śmierć była długim procesem, który zaczynał się w chwili śmierci i trwał dalej w rozkładzie zwłok. Ciało jako dzieło stworzenia Boga pozostawało złączone ze stworzonym przez Niego makrokosmosem. Oznaczało te, że natura i ludzkie społeczności były swoim odbiciem. Wszyscy ludzie odczuwali tę samą bezradność wobec niepewności, które przynosił los (Raber 102-104). 
można odnaleźć we Francji, w Hiszpanii, Włoszech, Szwajcarii, Niemczech, krajach bałtyckich i na wyspach brytyjskich (Cheney 182). Najstarszy mural znajdował się na paryskim Cmentarzu Niewiniątek (1425) ${ }^{20}$. Przedstawiał on taneczny korowód trzydziestu jeden postaci i ich zmarłych dublerów ustawionych w kolejności zgodnej z ówczesną hierarchią - od papieża do pustelnika. Bardzo podobne dzieło znajdowało się Die Lübecker Marienkirche, Lübecker Totentanz (Lubecki taniec śmierci, 1463) autorstwa Bernta Notke (1435-1509)21. W tanecznej procesji ukazano dwadzieścia jeden figur tańczących ze swoimi zmarłymi partnerami. Przewodził im przygrywający na piszczałce trup. $W$ obu przypadkach obraz był dopełniony krótkimi strofami poetyckimi na temat umierania. W myśl chińskiej zasady, że obraz jest wart tysiąca słów, danse macabre można interpretować jako wizualną kontemplację chrześcijańskich kazań dotyczących śmierci, przeznaczoną zwłaszcza dla ludzi niepiśmiennych. Wrażenie, które mógł on wywoływać na widzu było bezsprzecznie spotęgowane rzeczywistym rozmiarem tańczących, żywych i umarłych, którzy wydawali się dominować nad przechadzającymi się wzdłuż ścian ludźmi. Tańczący sprawiali wrażenie połączonych nieprzerywalną, jak życie i śmierć, więzią. W tym jednak kontekście, to śmierć dominuje nad żywymi, zmusza ich do tańca, przewodzi korowodowi, a ulegli wobec niej śmiertelnicy posłusznie trwają w nieprzerwanym ruchu (Gertsman 65).

$\mathrm{Na}$ wczesnych malowidłach europejskich żywi nie tańczyli ze szkieletami, ale z suchymi trupami przypominającymi mumie z lekko zarysowanymi kośćmi żebrowymi. Była to kontynuacja sposobu przedstawiania śmierci jako ludzkich zwłoki, zgodna ze wspomnianymi motywami(Kurtz 179). Większość zachowanych wizualizacji tańca śmierci powstało jednak na przełomie XIV i XV wieku i na ich podstawie można zauważyć powolną zmianę w percepcji uosobionej. Tańczący szkielet pojawił się po raz pierwszy we włoskim Danza macabra (1485) w Oratorio dei Disciplini w Clusone (Cheney 33-34). Mural ten jest o tyle wyjątkowy, że łączy w sobie dwa motywy śmierci: triumfu śmierci22 oraz danse macabre. Na samej górze umieszczono trzy szkielety: największy, środkowy stoi we władczej pozie, na głowie nosi koronę, a $\mathrm{z}$ ramion opada mu peleryna; po jego obu bokach dwa szkielety celują z broni do ludzi. Stoją na podwyższeniu z trumien dwóch papieży. $\mathrm{Na}$ dole ludzie klęczą przed nimi i przynoszą dary, jak gdyby błagali o litość. Poniżej umieszczono kilkunastu wykonawców typowego tańca śmierci, ale z kościotrupami. Mimo to idea przedstawiania śmierci jako szkieletu wydaje się niepopu-

${ }^{20}$ Zniszczony w XVIII wieku, ale zachowany w postaci drzeworytów z 1485 roku autorstwa Guyota Marchanta (?-?) (Gerstman 6).

${ }^{21}$ Dzieło zostało zniszczone podczas nalotu bombowego w 1942 r., ale zostało zachowane na fotografiach (Gertsman 105).

${ }_{22}$ Motyw ten był najpopularniejszy we Włoszech i przedstawiał śmierć jako apokaliptyczną figurę zabierającą życie przerażonym śmiertelnikom (Gertsman 25). 
larna w pozostałych krajach Europy: berliński mural Der Totentanz z Marienkirche (ok. 1490) ukazuje żywych tańczących z wychudzonymi zwłokami bez twarzy lub zaznaczonych kości. Z kolei we francuskiej kaplicy w Kermaria-an-Isquit (ok. 1490), na muralu wśród tańczących są również wyschnięte zwłoki, choć łatwo je pomylić ze szkieletami.

W późnym średniowieczu motywy te odegrały rolę moralnego kompasu społecznego. Europejskie murale, wkomponowane w ściśle religijne otoczenie, były głównie artystycznymi wizualizacjami moralizujących kazań. Wyśmiewały i odwracały hierarchię społeczną, podkreślając równość wszystkich ludzi w oczach śmierci. Równocześnie miały na celu przypominać o konieczności odpowiednich przygotowań zanim umierający wejdzie w zaświaty (Gertsman 164). Ich przesłanie nie osłabło, ale zmieniło się, kiedy śmierć i jej wpływ na życie przyjęły inny kształt i znaczenie w okresie Renesansu.

\section{Laicyzacja śmierci}

Wcześni nowożytni badacze i holistyczni fizjolodzy, tacy jak Thomas Linacre $^{23}$ (?1460-1524) czy Jean François Fernel24 (1497-1558) odziedziczyli poglądy na medycynę po poprzedniej epoce (Raber 103). Przedstawiali ciało jako mikrokosmos silnie złączony z makrokosmosem świata zewnętrznego. Pogląd ten wywodził się od starożytnej medycyny Galena25 (129-200/216) i teorii humo-

23 Thomas Linacre studiował grekę, łacinę oraz medycynę we Włoszech. W 1509 roku został nadwornym medykiem króla Henryka VIII (1491-1547; panował 1509-1547). Korzystając ze swojej uprzywilejowanej pozycji aktywnie działał na rzecz wprowadzenia greckiej medycyny w swojej ojczyźnie i przyczynił się do założenia pierwszego w kraju Royal College of Physicians w Londynie. Przetłumaczył także z greki na łacinę aż sześć dzieł Galena, w tym De Symptomatum differentiis et causis (1524). Więcej w W. Osler. Thomas Linacre: Linacre Lecture, 1908. Cambridge: Cambridge University Press, 2014. Oraz J. Noble Johnson. The Life of Thomas Linacre, Doctor in Medicine: Physician to King Henry VIII, the Tutor and Friend of Sir Thomas More. London, 1835.

${ }^{24}$ Jean François Fernel był francuskim patologiem, który wprowadził termin fizjologia. Należał do zwolenników teorii humoralnej Galena, ale odrzucił starożytne założenia dotyczące patologii. Jego największym osiągnieciem było spisanie kompendium Universa Medicina (1554) składającego się z trzech tomów: Physiologia, Pathologia i Therapeutice (Applebaum "Galenizm"; "Jean François Fernel”).

Teoria humoralna opierała się na medycynie starożytnej Grecji. Według niej ludzkie ciało składało się z czterech życiodajnych płynów (humorów): krwi, flegmy, żółci i czarnej żółci. Łączono je między innymi z czterema głównymi pierwiastkami, porami roku, barwami i temperamentami. Chorobę traktowano jako zewnętrzny przejaw braku wewnętrznej równowagi humoralnej (Ishida 1988: 55).

${ }^{25}$ Galen był jednym z najwybitniejszych starożytnych badaczy medycyny. Rozwinął i rozpowszechnił teorię humoralną, a także przyczynił się do rozwoju między innymi anatomii, patologii i neurologii. Choć w okresie renesansu zaczęto podważać jego teorie, założenia Galena były podstawą medycyny aż do XVII wieku (Applebaum „Galenizm”). 
ryzmu ${ }^{26}$. Jednak związek pomiędzy żywym ciałem a zwłokami pozostał ambiwalentny. Moment śmierci był wciąż niejasny. Umiejętność stwierdzania zgonu była na niskim poziomie i trudność sprawiało odróżnienie śmierci od stanu śpiączki (Johnson 185). Dalsze pytania dotyczące natury ciała, jego szczątków i samego ja człowieka były otwarte na interpretacje w zmieniającym się środowisku naukowym (stopniowa profesjonalizacja medycyny), teologicznym (reformacja) i humanistycznym.

Przyszłe renesansowe zmiany zwiastowała kolekcja drzeworytów Der Totentanz (1538) autorstwa Hansa Holbeina ${ }^{27}$ (1497-154). Pomimo sukcesu komercyjnego i wielokrotnych wznowień, niewiele wiadomo o inspiracji i procesie artystycznym autora. Dzieło powstawało w Bazylei w latach 1522-1526, zostało wydrukowane około 1526 roku i opublikowane dopiero dwanaście lat później. Opóźnienie wynikało prawdopodobnie z obaw, jakie mieli wydawcy wobec ewentualnej reakcji odbiorców na satyryczny ton i dosyć ryzykowną interpretację śmierci (Kurtz 191). Możliwe, że Holbein stworzył swoje drzeworyty na wzór wiersza Le Mors de la Pomme28 (ok. 1470), obok którego zamieszczono miniaturki artystyczne przedstawiające śmierć w sposób podobny jak w Der Totentanz ${ }^{29}$. Ze względu na to, że drzeworyty powstały w okresie reformacji, można by je interpretować jako protestanckie, jednak ostateczny ton, katolicki lub reformacyjny, oraz intencja autora zależały $\mathrm{w}$ znacznym stopniu od sentencji, którymi były podpisane ${ }^{30}$.

Niemniej historycy uznają dzieło Holbeina za niezaprzeczalny przełom $\mathrm{w}$ przedstawianiu śmierci (Clark 3). Artysta ten zerwał bowiem z tradycją ogromnych murali i zmniejszył je do formatu książki. Choć rozmiar nie był już tak przytłaczający, pozwoliło to na wywołanie u odbiorcy indywidualnej, intymnej reakcji (Gertsman 174). Holbein porzucił także konwencję tanecznego

26 Patrz przypis 23.

27 Właściwie Hans Holbein Młodszy, niemiecki artysta specjalizujący się głównie w portretach, malarstwie sakralnym i drzeworytach. Tworzył w stylu gotyckim połączonym $\mathrm{z}$ włoskimi renesansowymi technikami malarskimi. Więcej w: O. Bätschmann. Hans Holbein: Revised and Expanded Second Edition. London: Reaktion Books, 2014.

${ }^{28}$ Le Mors de la Pomme to anonimowy wiersz o charakterze dydaktycznym. Poruszono w nim temat grzechu pierworodnego oraz pojawienia się śmierci w ludzkim świecie. Autor wykorzystał homofonię rzeczowników franc.: mors ([kęs, kawałek] od czasownika mordre [gryźć]) oraz mort ([śmierć] od czasownika mourir [umierać]) (Muir 202).

29 Więcej w (Kurtz 56).

${ }^{30}$ Wydawcami pierwszej edycji byli bracia Caspar(?-?) i Melchior Trechsel (?-?) z Lyonu, którzy zatrudnili poetę Gillesa Corrozeta (1510-1568) do napisania wersów uzupełniających drzeworyty. Wszyscy z nich byli oddanymi katolikami i w takim duchu też wydano dzieło. Z drugiej strony w 1542 roku bracia Jean (?-1570) i François Frellon (?-1546?) z Lyonu opublikowali dzieło Holbeina, ale opatrzyli je protestanckimi esejami. Autorytety teologiczne odłamu rzymskokatolickiego zakazały tego wydania, podczas gdy wyraziły one zgodę na obieg publikacji braci Trechsel. Więcej w (Gertsman 172-173). 
korowodu. W zamian skupił się na ukazaniu bohaterów w otoczeniu odpowiednim dla ich pozycji społecznej. Dzięki temu każda scena wchodząca w skład kolekcji drzeworytów stała się pojedynczym aktem śmierci. Podobny zamysł pojawił się $\mathrm{w}$ trzynastowiecznych wierszach vado mori 31 (zmierzam ku śmierci). Osoby mówiące $\mathrm{w}$ utworze opisywały własną śmierć, która była odpowiednia dla ich pozycji lub zawodu. Indywidualizacja śmierci dla danej grupy społecznej jest - jak można zauważyć - wspólna zarówno dla wierszy, jak i drzeworytów Holbeina, jednak główna różnica polega na tym, że w utworach literackich obecność śmierci jako bytu nie jest wyodrębniona w taki sposób jak u niemieckiego artysty (Gertsman 37). Gdyby przyjąć, że główną bohaterką Der Totentanz była śmierć, mógłby on być interpretowany jako ilustrowany przewodnik, przedstawiający jej historię. Holbein rozpoczął swój cykl od Stworzenia i Wygnania z raju, co mogło być aluzją do przekonania o tym, że śmierć pojawiła się w świecie ludzi, jako skutek grzechu pierworodnego. Następnie artysta przedstawił różne zachowania śmierci i jej interakcje z przedstawicielami danych warstw społecznych. Całość zakończył na scenie Sądu Ostatecznego, czyli na tym, do czego ewentualnie miała prowadzić śmierć. $W$ tych ekspresyjnych dziełach sztuki rządzą nieznające litości szkielety, które nie tylko tańczą i grają na instrumentach, ale idealnie wpasowują się w otoczenie i samodzielnie wybierają swoje ofiary. Śmierć zaskakuje swoją ofiarę, przerywa jej codzienną rutynę i na siłę odciąga od bliskich. Dobrze wie, jak sprawić żywym największy ból i skrupulatnie wybiera przedmioty, do których czują największe przywiązanie, aby je odebrać. Śmierć według Holbeina jest niespodziewana i momentalna, nie jest już długim procesem, który umożliwia godne przygotowanie się na swój koniec. $Z$ tego powodu można stwierdzić, że Holbeina bardziej interesowała reakcja ludzi na okrutny los, który zmusza ich do rozstania się z ukochanym życiem. Większość śmiertelników wygląda na zdezorientowanych i nieprzygotowanych do opuszczenia świata dóbr doczesnych. Śmierć zaczęła być postrzegana jako niechciany, ale nieuchronny towarzysz żywych. Interpretacja ta rozwijała się w kolejnych wiekach, podczas gdy nauka przysłużyła się do popularyzacji szkieletu, jako obrazu śmierci i zainicjowała ostatni etap procesu jej personifikacji (Cheney 182).

Sekcje zwłok wykonywano już w starożytności i średniowieczu ${ }^{32}$, ale upowszechniły się one dopiero $w$ czasach nowożytnych (McTavish 17). Kiedy

${ }^{31}$ Vado mori składały się z dwuwersowych strof, które zawierały krótkie wypowiedzi ludzi rozpaczających nad nieuchronną śmiercią. Każda z osób kończyła swój lament słowami vado mori (Gertsman 37).

32 Sekcje zwłok były częścią treningu medycznego, ale praktyka ta nie stanowiła fundamentu w dziedzinie anatomii. Były one rzadkie i oparte na starożytnych tekstach oraz pamięci i wiedzy danego wykładowcy (Salmón 79). 
w 1543 roku Andreas Vesalius ${ }^{33}$ (1514-1564) opublikował atlas ludzkiej anatomii De humane corporis fabrica, stał się on fundamentalnym renesansowym dziełem $\mathrm{w}$ tej dziedzinie. Wyniki badań Vesaliusa oparte na rzeczywistych sekcjach zwłok z sukcesem zdyskredytowały przestarzałe teorie Galena (Broomhall: 90). Atlas flamandzkiego naukowca to działające na ludzką wyobraźnię dzieło. Można powiedzieć, że poddane sekcji ludzkie ciało zostało ujęte w niezwykle artystyczny sposób ${ }^{34}$. Inni praktykujący medycy w Europie zaczęli wypowiadać się bardzo otwarcie na temat swoich odkryć i chętnie publikowali medyczne opisy, uzupełnione o szczegółowe ilustracje wnętrza ciała (Broomhall 75; McTavish 27). Można powiedzieć, że w ten sposób zwłoki zostały wystawione na widok publiczny, ale w nowym, dalekim od rytuałów pogrzebowych kontekście. Należy jednak pamiętać, że interpretacja odkryć medycznych nie była wolna od wpływu ewoluujących równolegle nauk humanistycznych. Obie dziedziny wzajemnie się przeplatały i zmieniały. To ich interakcje wpłynęły na ukształtowanie poglądów na temat funkcjonowania organizmu, zdrowego trybu życia, choroby i na ogólną postawę wobec ludzkiego ciała i zwłok (Broomhall 73). Oznacza to, że profesjonalni medycy nie mieli monopolu na zmieniający się dyskurs, ponieważ także artyści, filozofowie, duchowni, a nawet zwyczajni ludzie opracowywali, głosili i przedstawiali własne jego interpretacje. Kościół katolicki kontrolował nowe odkrycia anatomiczne, przedstawiając je jako kunszt boskiego stworzenia. Duchowni sprawdzali ponadto, które choroby były uleczalne przez naturę, a które tylko przez boską interwencję, inaczej mówiąc rozróżniali choroby będące wynikiem woli Boga od chorób sprowadzonych przez Szatana. W renesansie ciało ludzkie wciąż było uważane za obdarzone świętą naturą, co wyrażano przez kult świętych i szacunek wobec szczątków (Broomhall 78). Z drugiej strony, kościół protestancki kwestionował takie założenia i próbował ograniczyć rytualizację śmierci. Zmarli wciąż byli obiektem czci, ale zwłoki widziano bardziej, jako fizyczne ciało i kości, aniżeli jako sentymentalną pamiątkę łączącą żywych ze zmarłymi. Zgodnie z tym podejściem, możliwe było przeprowadzanie sekcji zwłok, a to korespondowało z nowym dyskursem medycznym (McTavish 29-30). Renesansowe społeczeństwa były odbiorcami różnych koncepcji dotyczących zrozumienia ludzkiego ciała, zarówno przed, jak i po śmierci. Dopiero pod koniec okresu ugruntowało się podejście racjonalistyczne. Na jego podstawie osta-

33 Andreas Vesalius był flamandzkim anatomistą i nadwornym lekarzem cesarza Karola V Habsburga (1500-1558; panował 1519-1556). W swoich badaniach potwierdził błędy Galena dotyczące budowy serca i opisał każdy mięsień ludzkiego ciała. Uważał także, że ludzki szkielet stanowi rusztowanie dla całego ciała, a mózg centrum myśli i uczuć człowieka (Applebaum „Vesalius”).

${ }^{34}$ Ilustracje anatomiczne przypisuje się uczniom z pracowni Tycjana (1488/1490-1576), w tym Janowi Stevenowi van Calcarowi (1499-1546). Więcej w C.D. O'Malley, Andreas Vesalius of Brussels 1514-1564. Berkeley and Los Angeles: University of California Press, 1964. S. 111-138. 
tecznie ustalono związek pomiędzy żywymi i umarłymi: oddzielono ciało fizyczne od środowiska zewnętrznego, ludzki organizm traktowano jako indywidualny system, a oba były różne od abstrakcyjnego pojęcia ja (Raber 104).

Renesans był okresem kształtowania się różnych postaw wobec śmierci. Naukowe, racjonalistyczne idee mieszały się z humanistycznymi interpretacjami oraz wierzeniami religijnymi i teologicznymi. Definitywne rozdzielenie duszy od ciała oraz rozwiązanie zagadki ludzkiego wnętrza wpłynęły na wyobraźnię artystów i odbiorców sztuki, a obrazy szkieletów stworzone przez Holbeina osiągnęły nowy poziom artystycznego wyrazu. Paradoksalnie martwe kości obdarzono życiem (Ariès 1985: 184). Smierć się zlaicyzowała i zaczęła być przedstawiana jako indywidualna persona, aktywny suchy szkielet zamiast powielonych wysuszonych zwłok (Schuster 218). Chociaż postać kościotrupa zastąpiła średniowieczne memento mori, została jednocześnie włączona do codziennego życia żywych. Szkielet był echem ludowych wierzeń w możliwość rezurekcji, ale renesansowe idee unowocześniły go. Zaczął brać czynny udział w codzienności śmiertelników: kradł, śmiał się z nich, przebierał w ich ubrania i zakochiwał w pięknych kobietach. Nowa Śmierć miała swoje własne charakterystyczne cechy, jak sardoniczny uśmiech, charakterystyczny chód i ekspresywny wyraz oczu (Ariès 1985: 176). To przedstawienie było kontynuowane $\mathrm{w}$ kolejnych epokach, a szkielet, jako symbol śmierci, ugruntował się i pozostał popularny. Używano go, jako symbolu przemijającej natury ludzkiego życia, ale także jako postać komiczną w politycznej satyrze (Ariès 1985: 193). W wyniku personifikacji śmierci jako szkieletu mgła niezrozumienia stała się rzadsza. Ludzie uświadomili sobie swoje powolne umieranie, ale nie w sposób, w jaki pragnęli tego średniowieczni duchowni. Nie można zaprzeczyć, że żywi odczuwali kruchość życia, ale zamienili wszczepiony przez Kościół strach w pasję do życia (Cheney 34).

\section{Unikanie nieuniknionego}

Podczas gdy Europejczycy połączyli żal za uciekającym życiem z akceptacją bliskiej śmierci, Japończycy mieli całkowicie inny psychiczny mechanizm obronny przed nieuniknioną śmiercią. Od początku kształtowania się praktyk religijnych, był on zanurzony $\mathrm{w}$ ich własnym synkretycznym świecie zjawisk nadprzyrodzonych. Wiara $\mathrm{w}$ istnienie i obecność duchów w ludzkim świecie mogła wynikać $\mathrm{z}$ adaptacji chińskiej filozofii yin yang i to na długo przed pierwszymi japońskimi kronikami z początku VIII wieku35. Według niej dusza składała się z, co najmniej,

\footnotetext{
${ }^{35}$ Do tego czasu zaimportowano już wiele elementów kultury chińskiej, między innymi konfucjanizm, buddyzm oraz taoizm. Niestety wszelkie informacje dotyczące wcześniejszego okresu w historii
} 
dwóch elementów, jasnego i ciemnego, które ulegały rozdzieleniu w chwili śmierci. Dusza yang udawała się do zaświatów, a dusza yin pozostawała na ziemi (Scheid 213). Wierzono także, że w przypadku nagłej, niespodziewanej śmierci dusza mogła przywiązać się do miejsca zgonu i być źródłem niezwykłych zjawisk ${ }^{36}$, na przykład dziwnych odgłosów, niewyjaśnionych zdarzeń, a nawet nieszczęść, jeśli duch był mściwy (Yokoyama 29). Z drugiej strony, duch mógł chronić żyjących potomków i uczestniczyć $w$ ich codziennym życiu. Spowodowało to, że śmierć rozumiano jako następny poziom egzystencji (Niwa 90). Unikano tego tematu i nie poświęcano mu zbyt wiele uwagi w źródłach pisanych. Nieliczne opisy przedstawiały zaświaty jako miejsce mroczne i owiane mgłą tajemnicy ${ }^{37}$. Ogólnie, różnego pochodzenia idee i koncepcje mieszały się ze sobą, zmieniając wyobrażenia na temat mistyki śmierci.

Jednocześnie podejście do fizycznego aspektu śmierci było bardzo negatywne. Ciało ludzkie traktowano jedynie jako naczynie dla duszy, które traciło swoją wartość w chwili śmierci(Niwa 90). Odrzucenie martwych szczątków prawdopodobnie sięgało pierwotnych animistycznych wierzeń, nazwanych później shintō (droga bóstw), według których bóstwa nie tolerowały nieczystości. W razie ewentualnego zbrukania miały zsyłać klątwę na ludzi w postaci epidemii i/lub katastrof naturalnych (Katsuda 4). Najstarsze ślady opisów śmierci jako źródła nieczystości zawarto w kronice Kojiki (Księga dawnych wydarzeń, 712) ${ }^{38}$. W jednym z mitów

Japonii zostały zapisane dopiero w VIII wieku. Należy wziąć pod uwagę możliwość, że twórcy japońskiej historii i mitologii inspirowali się obcymi wzorcami i zawarli w pismach treści nie do końca rodzime. W Kojiki (Księga dawnych wydarzeń, 712) zawarto opis mrocznego miejsca, którego nazwa yomi no kuni (kraina ciemności) nawiązywała do chińskiej mitologii. Z kolei w Nihonshoki (Kronika Japonii, 720) znalazły się odniesienia do dualistycznej koncepcji duszy. Więcej w Shinbo S. Nihonjin no shiseikan. Nihonbunka no konpon o motomete [Japońskie poglądy na życie i śmierć. W poszukiwaniu źródeł japońskiej kultury. Okayama: Daigaku Kyōikushuppan, 2009. Tamura Y. (red.). Nihon ni okeru sei to shi no shisō [Ideologia życia i śmierci w Japonii]. Tōkyō: Yūhikaku, 2009. Filozofia ying yang opierała się na koncepcji współzależności dwóch pozornie przeciwnych sił yin (ciemność) i yang (jasność). W rzeczywistości jednak stanowiły one swoje uzupełnienie (Scheid 216).

${ }^{36}$ Przekonanie to prawdopodobnie pochodzi z Chin. Na kontynencie uważano, że jeżeli zmarły nie zostanie właściwie pochowany, po śmierci stanie się on złym duchem (Hori 43).

${ }^{37} \mathrm{Na}$ podstawie utworów z antologii poezji Manyōshū (Zbiór dziesięć tysięcy liści, 780) można stwierdzić, że śmierć była uważana za kolejny etap egzystencji. Temat ten podejmowano w pośredni sposób i moment śmierci opisywano jako odejście do dalekiej krainy ukrytej w chmurach (Ebersole 81). Prawdopodobnie jest to nawiązanie do prymitywnych wierzeń, według których góry uważano za miejsce zmarłych lub/oraz za punkty, w których świat rzeczywisty i zaświaty spotykały się (Hori 151).

${ }^{38}$ Kojiki (Ksiega dawnych wydarzeń) jest najstarszym zachowanym dziełem piśmiennictwa japońskiego, zawierającym mity, legendy, wiersze, genealogię i historyczne zapiski od czasów boskich do okresu panowania cesarzowej Suiko (554-628; panowała 593-628). Składa się z trzech ksiąg poprzedzonych wstępem w języku chińskim, według którego cesarz Temmu (631-686; panował 673-686) zlecił Hieda no Are (?-?) zgromadzenie między innymi historii rodu cesarskiego, starych opowieści 
Izanagi39, nie mogąc pogodzić się ze śmiercią żony Izanami, zszedł do jaskini uważanej za przejście do świata podziemnego. Piękna bogini pokazała się mężczyźnie, ale nakazała mu odejść. Zauroczony urodą żony, Izanagi zignorował ostrzeżenia i przekroczył niewidzialną granicę pomiędzy światami. Nagle zobaczył prawdziwy wygląd swojej ukochanej - zwłoki w stanie rozkładu toczone przez codziennie będzie zabijała tysiąc osób. Po wizycie w podziemiach, czując się zbrukanym, Izanagi wypełnił rytuał oczyszczenia wodą (Kotański 57). Mit ten można zinterpretować jako wyjaśnienie obecności śmierci w świecie ludzi. W tej krótkiej historii zawarto także stosunek ówczesnych Japończyków do umierania. Po pierwsze, świat żywych i umarłych naturalnie były oddzielone niewidzialną linią, ale przykro doświadczony Izanagi zaznacza wyraźną granicę, ustawiając na niej kamień. Kontrast pomiędzy życiem i śmiercią jest także silnie zarysowany w reakcji męża na wygląd żony: piękno zmieniło się w brzydotę. Zachodzi tu proste skojarzenie z pięknem życia i brzydotą śmierci. Takie graficzne rozróżnienie można interpretować jako kolejną próbę odseparowania człowieka od trupa. Po drugie, mit kończy się na rytualnym oczyszczeniu, które miało zmyć zbrukanie po bezpośrednim kontakcie ze śmiercią. Może to świadczyć o tym, że co najmniej w VIII wieku istniało już przekonanie o nieczystości śmierci ${ }^{40}$.

Idea ta ewoluowała w przeświadczenie o istnieniu kegare, czyli zbrukania, które mogło dotyczyć zarówno zjawisk, jak i ludzi. Uważano, że kegare było jak zaraźliwa choroba, którą przekazywano przez bezpośredni kontakt z czymś lub kimś skalanym. Eskalacja strachu miała miejsce w okresie Heian (794-1185) i objęła głównie warstwę arystokratyczną. Przede wszystkim obawiano się, że nosiciel kegare mógł bezwiednie zarazić pałac cesarski i przodków cesarza, co prowadziło do gniewu bóstw i ewentualnej klątwy. Wierzenia były na tyle silne, że koncepcja ta była traktowana jako realne niebezpieczeństwo dla funkcjonowania społeczeństwa i państwa. Już od VIII wieku japońskie kodeksy prawne zawierały przepisy, w których dokładnie opisano ograniczenia związane z kegare. Są w nich wzmianki o: odseparowywaniu zarażonych; dopuszczalnej ilości razy przeniesienia zbrukania na innych; osobach odpowiedzialnych za znajdowanie źródeł nieczystości i ich usuwanie; osobach mających przeprowadzać rytuały przebłagalne ${ }^{41}$.

i wierszy. Redaktorem kroniki był Ō no Yasumaro (?-723). Więcej w M. Melanowicz. Historia literatury japońskiej. Warszawa: Wydawnictwo Naukowe PWN, 2011. S. 36. Wydanie w języku polskim Kojiki czyli księga dawnych wydarzeń, W. Kotański (tłum.)Warszawa 1986.

39 Izanagi i Izanami to para bóstw z siódmego pokolenia tzw. bóstw początku. Są uznawani za praojca i pramatkę, którzy dali początek japońskim wyspom i licznym bóstwom (Tubielewicz 114).

${ }^{40}$ Sporną kwestią wciąż pozostaje to, czy była to koncepcja rodzima, czy zapożyczona z kontynentu.

${ }^{41}$ Zapisy dotyczące kegare były częścią kodeksów prawnych aż do XIX wieku. Więcej w Nakagawa M., Kinsei no shi to seiji bunka. Narimono Teishi to kegare [Kultura śmierci i polityki w nowożytności. Zakaz dźwięku a nieczystość]. Tōkyō: Yoshikawa Kōbunkan, 2009. S. 167-169. 
Pogląd dotyczący nieczystości zwłok miał też wpływ na rytuały pogrzebowe. Unikanie zbrukania dotyczyło głównie arystokracji. Zdarzało się, że wysoko postawieni urzędnicy umierali $\mathrm{w}$ samotności, $\mathrm{w}$ specjalnym budynku, aby uchronić własną rodzinę przed konsekwencjami z nim związanymi. Wśród zwykłych ludzi typowym pochówkiem było wyrzucanie zwłok na ulicę ${ }^{42}$. Ten oraz inne zwyczaje pogrzebowe z późnego okresu Heian przedstawiono na ilustrowanym zwoju Gakizōshi (Głodne duchy, XII wiek). Były to pozostawione w otwartej trumnie zwłoki, którymi pożywiały się zwierzęta, porzucone na ziemi ciała, ludzki szkielet, rozrzucone kości ssane przez głodne duchy ${ }^{43}$ - wszystkie powszechne wśród niższych klas społecznych (Nakamura 216).

Wydawałoby się, że buddyzm, w którego oficjalnej doktrynie poświęca się niewiele uwagi pojęciu „nieczystości” złagodzi strach wobec kegare. Choć z początku mnisi krytykowali tabu, to w miarę postępującego procesu asymilacji z shintō, sami zaczęli przestrzegać praw dotyczących unikania zbrukania ${ }^{44}$. Na dodatek przekonanie o nieczystości zwłok nie tylko umocniło się, ale zaczęło dotyczyć także żywego ludzkiego ciała. Uważano, że człowiek przez swoje przywiązanie do ziemskich dóbr i doczesnego świata już za życia wystawiał się na zbrukanie. Na przykład sądzono, że niektóre kegare są stałe i nie można się z nich oczyścić. Pogląd ten dotyczył przede wszystkim kobiet (krew miesięczna, poród) oraz członków pogardzanych grup społecznych (m.in. chorzy na trąd). Uważano, że powodem ich niskiej pozycji jest zło, które zostało przez nich popełnione w poprzednim życiu i które wciąż w nich tkwi (Stone 176-177). Mnisi sprzeciwiali się również wystawianiu szczątków na widok publiczny, gdyż twierdzili, że widok rozkładającego się ciała powodował cierpienia duszy (Nakamura 219). Pogląd ten można połączyć ze zwojami kusōzu (dziewięć etapów rozkładu45), których graficzne wer-

42 Właściwy system pochówków danka został ustanowiony na początku XVII wieku. Prawo do legalnego pogrzebu mieli tylko ci, którzy przynależeli do jednej z buddyjskich świątyń. Był to sposób na ograniczenie działalności misyjnej chrześcijan (Nagasawa 106).

${ }^{43}$ Gaki pochodzą ze świata o jeden poziom wyższego niż piekło. Duchy te zostały skazane na niezaspokajalne pragnienie danej substancji, takich jak krew, odchody, ludzkie zwłoki. Więcej w J. Wilson (red.). Lafcadio Hearn: Japan's Great Interpreter: a New Anthology of His Writings, 1894-1904. Kent: Psychology Press, 1992.

${ }^{44}$ Stanowisko buddyjskich mnichów wobec kegare nie było jednoznaczne. Niektórzy mnisi buddyjscy próbowali wzbudzać w ludziach współczucie i szacunek wobec zwłok, jednakże byli oni traktowani jak zbrukani. Z tego powodu wielu mnichów dostosowywało się do prawa kegare. Więcej w J.I. Stone. „Dying Breath: Deathbed Rites and Death Pollution in Early Medieval Japan”. Heroes and Saints: The Moment of Death in Cross-Cultural Perspectives. Red. P. Granoff, K. Shinohara. Newcastle, 2007, s. 190-194.

Z względu na rozległość problemu asymilacji shintō oraz buddyzmu, temat ten nie został podjęty w poniższym artykule. Szczegóły w Stone 175-190.

${ }^{45}$ Choć zdarzają się także przedstawienia rozkładu zwłok w mniejszej lub większej ilości etapów. 
sje stały się popularne w XIII-wiecznej Japonii ${ }^{46}$. Były to bardzo dokładne oparte na obserwacji zwłok, choć niepoprawne anatomicznie, studia nad rozkładającym się ciałem kobiety. Zwoje te zwykle przedstawiały wariacje następujących etapów: tuż po śmierci, rozdęcie ciała, wypłynięcie płynów fizjologicznych, gnicie, pożarcie przez zwierzęta, zsinienie, szkielet, rozrzucone kości, nagrobek (Chin 281). Mnisi buddyjscy używali kusōzu m.in. w celach kontemplacyjnych oraz dydaktycznych (kazania z użyciem etoki; Chin 282). Miały one ostrzegać przed przywiązaniem do dóbr ziemskich, nieczystością ciała. Mnich lub wierny miał je odrzucić w celu osiągnięcia szczęśliwego życia po śmierci (Chin 294).

Można założyć, że do tego momentu (XIV wiek) wiedza o istnieniu szkieletu wewnątrz ludzkiego ciała była powszechna, a same kości w naturalny sposób kojarzyły się fizyczną śmiercią. Za racjonalnością tego założenia przemawia historia średniowiecznej Japonii. Był to okres politycznej niestabilności, konfliktów, wojen, głodu i epidemii. Oprócz szczątków wyrzucanych w rytuałach pogrzebowych ulice były wypełnione poległymi w walkach lub zmarłymi z powodu epidemii (Nakamura 217). Takie okoliczności prawdopodobnie miały wpływ na ówczesne społeczeństwo, jednakże temat śmierci fizycznej pozostawał tabu. Szczątki pozostawały nieruchome, a nawet bierne w porównaniu do złego ducha, który mógł w nich mieszkać. Odpowiedzialność za zajmowanie się śmiercią spadła na hinin (nie-ludzie), członków powszechnie potępianej społeczności, którzy tak jak śmierć byli uważani z natury za nieczystych ${ }^{47}$.

\section{Kegare a nauka}

Ze strachem wobec ludzkiego ciała borykała się też medycyna. Japońska sztuka lekarska opierała się w głównej mierze na zaimportowanej z Chin między V a VI wiekiem Teorii przemian pięciu pierwiastków ying yang (jap. Inyōgogyōsetsu; 770 p.n.e.) ${ }^{48}$. Według tej teorii ciało człowieka (mikrokosmos) było połączone z wszechświatem (makrokosmos) skomplikowaną siecią zależności. Uważano, że

${ }^{46}$ Były popularne do okresu Edo (1603-1868).

47 Hinin należeli do klasy wyrzuconej poza społeczeństwo ze względu na wykonywany zawód związany z nieczystościami, na przykład wywóz ludzkich zwłok z miasta, wykonywanie kary śmierci, rzeźnictwo, grabarstwo. Istnieją teorie, że zostali oni odizolowani ze względu na trąd kilka wieków wcześniej (Katsuda 207-210; Honda 6).

48 In'yō gogyō setsu (chin. yinn yáng i wu xin) to połączenie zasady yīng yáng i teorii pięciu pierwiastków. Opierało się na przekonaniu, że wszechświat był zbudowany z pięciu głównych pierwiastków: drewna, wody, ziemi, ognia i metalu. W chińskiej medycynie elementy te odpowiadały konkretnym zestawom kolorów, pór roku, kierunkom świata, organom wewnętrznym, wydzielinom, czy smakom. Jeśli jeden z pierwiastków był w stanie nierównowagi, objawiało się to symptomami odpowiednimi dla danej choroby (Bowers 10-11). 
zranienie ciała, nawet w celu wyleczenia go, zaburzało równowagę między nimi, co mogło prowadzić do strasznych konsekwencji. Większość medyków odrzucało leczenie urazów oraz przeprowadzanie sekcji zwłok i polegało głównie na medycynie internistycznej (Bowers 11-13). Taka postawa doprowadziła do braku rozwoju wiedzy na temat śmierci. Jednocześnie zwiększyła się przestrzeń dla nowych wierzeń i praktyk ludowych dotyczących śmierci, między innymi codziennie obserwowano ciało zmarłego w celu potwierdzenia zgonu, uważano, że proces rozkładu był odbiciem procesu duszy opuszczającej ciało. Wierzono także w możliwość ponownego ożycia zmarłego (Niwa 91-92). Mimo negatywnego nastawienia do niej, medycyna zewnętrzna rozwijała się od początku w bardzo ograniczonym zakresie, nawet $\mathrm{w}$ okresie konfliktów militarnych, aż do końca XVII wieku. Niektórzy japońscy medycy próbowali przełamać prymat chińskiej medycyny: samodzielnie prowadzili badania i przeprowadzali sekcje zwłok, ale ich działania oraz wyniki spotykały się z ostrym sprzeciwem środowiska ${ }^{49}$. Szansa na zmiany pojawiła się w drugiej połowie XVIII wieku. W 1774 roku Sugita Genpaku (1733-1817) i Maeno Ryōtaku (1723-1803) ${ }^{50}$ opublikowali Kaitaishinsho (Nowy opis budowy ludzkiego ciała ${ }^{51}$ ), japońskie tłumaczenie europejskiego atlasu anatomii (Ishida 2007: 226). Przedstawili oni $w$ ten sposób 52 nie tylko wysoki stopień zaawansowania badań w Europie, ale także konkurencję dla mniej aktualnej chińskiej medycyny (Ishida 2007: 226). Publikacja zachęciła japońskich badaczy do podjęcia studiów nad nieznaną dotąd medycyną. Niektórzy z nich wyrażali jednak wątpliwości wobec inwazyjnych i radykalnych metod. Okazało się, że choć wielu popierało ideę przeprowadzania sekcji zwłok w celach naukowych, dokonywanie konkretnych skecji było zbyt ryzykowne dla Japończyków, którzy pozostawali wciąż w silnym uścisku tabu śmierci. Zamiast praktyki naukowcy i artyści zadowolili się

49 Patrz Yamawaki Tōyō (1706-1762). Więcej w Sugimoto T., Kaitaishinsho no jidai. Edo no bunka no hon'yaku wo saguru [Wiek Kaitaishinsho. W poszukiwaniu tłumaczenia kultury Edo].Tōkyō: Waseda Daigaku Shuppanbu, 1987. S. 189.

50 Sugita Genpaku był lekarzem, który uczył się podstaw zachodniej chirurgii od ojca, a następnie kontynuował naukę u Nishiego Gentetsu (1681-1760), nadwornego lekarza sioguna Tokugawa Yoshimune (1684-1751). Maeno Ryōtaku również został wychowany w kręgu nauki medycyny, ale bardziej interesowała go nauka języka holenderskiego (Tubielewicz 303, 188).

${ }^{51}$ Właściwy tytuł brzmiał Kaibōgakuhyō (Tablice anatomiczne). W rzeczywistości była to japońska interpretacja holenderskiego tłumaczenia niemieckiego Anatomische Tabellen (Tablice anatomiczne; 1722) autorstwa Adama Kulmusa (1689-1745). Więcej w Ishida S. Oranda ni okeru rangakuisho no keisei (Powstawanie opracowań medycznych rangaku w Holandii). Kyōto: Shinbunkaku, 2007. S. 21.

52 Decydująca o wszystkim sekcja zwłok odbyła się w 1771 roku w Kozukaharakeijō (Miejsce egzekucji w Kozukahara), gdzie wykonywano karę śmierci w Edo. Została ona przeprowadzona przez człowieka należącego do hinin. Przez wiele wieków mieli oni stały dostęp do zwłok i posiadali szeroką wiedzę na temat ludzkiego ciała. Znali pozycję organów, wiedzieli, gdzie należy ciąć kości i jak odzyskać żółć uznaną za lekarstwo na problemy gastryczne. Zdarzało się, że lekarze zatrudniali ich jako pomocników, kiedy sami nie chcieli dotykać zwłok (Honda 114; Keene 16). 
kopiowaniem europejskich ilustracji anatomicznych. Stały się one podstawowym źródłem wiedzy anatomicznej, a realistyczny styl zachodniego malarstwa idealnie nadawał się do odwzorowywania budowy ludzkiego organizmu na papierze (Screech 76).

\section{Magia w kościach}

Nowe techniki malarskie pozwoliły wiernie odtwarzać otaczającą artystów rzeczywistość. Z biegiem czasu artyści przenieśli swoje zainteresowanie na pełen nieprzewidywalnych duchów świat nadprzyrodzony (Yokoyama 17). Do tej pory magiczne istoty ${ }^{53}$ pozostawały niewidzialne i budziły strach. Bóstwom składano ofiary, prosząc o ochronę przed nimi. Popularne były także amulety mające odstraszyć nieproszonych gości z zaświatów. Artyści natomiast postanowili je zinterpretować jako postaci o różnych kształtach i osobowościach (Yokoyama 50). Na wzór atlasów anatomicznych powstawały atlasy rozrywki przedstawiające znane już postaci nadprzyrodzone $\mathrm{w}$ zabawnych, a nawet wzbudzających współczucie sytuacjach. Pozwoliło to na rozliczenie się z dotychczasowym dziedzictwem kultury jakim był japoński świat magii. Biorąc pod uwagę, że twórcy zyskali nowe umiejętności w wyniku kopiowania ilustracji medycznych, można powiedzieć, że pojawienie się szkieletu w sztuce było naturalną koleją rzeczy: na przełomie XVIII i XIX wieku kości w końcu ożyły. W świecie artystycznym ruchomy kościotrup należał do kolekcji licznych postaci nadprzyrodzonych. Koncepcja szkieletu jako siedliska mocy paranormalnych nie była nowa. Istniała w ludzkiej wyobraźni na długo przed przełomem $\mathrm{w}$ medycynie i fascynacją Zachodem. Trudno definitywnie ustalić źródła tego wyobrażenia, ale można podążyć za motywem, który powtarza się na drzeworytach kilku artystów, jak między innymi Utagawa Hiroshige (1795-1858) Taira Kiyomori kaii wo miru zu (Taira Kiyomori54 widzący duchy, 1845), Katsushiki Hokui (?-?) Fukuhara ${ }^{55}$ densha kaii no zu (Zjawy w pałacu w Fukuharze, 1843-1847), Tsukiokiego Kunitoshi (1839-1892) Taira Kiyomori Fukuhara ni sūhyaku

\footnotetext{
53 Obecnie znane pod kolektywną nazwą yōkai (magiczne postaci). Należały do nich zarówno duchy tradycyjne, jak i te wymyślone w okresie Edo (Komatsu 205).

54 Taira Kiyomori (1118-1181) był pierwszym przywódcą militarnym, którego działania przyczyniły się do wzrostu znaczenia klasy wojowników. Po odniesieniu zwycięstw w tzw. zamieszkach ery Hōgen (Hōgen no ran) 1156 r. i zamieszkach ery Heiji (Heiji no ran) w 1159 r. umocnił swoją pozycję na dworze. W 1167 roku otrzymał najwyższy tytuł Ministra Stanu (jap. dajō daijin) przeznaczony dla osób będących wzorem dla całego cesarstwa. Utrzymywał dominację rodu w kręgach politycznych dzięki małżeństwom córek z potomkami rodziny cesarskiej i nominacjom krewnych na wysokie stanowiska. W 1180 roku w wyniku intryg udało mu się osadzić na tronie swojego wnuka, cesarza Antoku (1178-1185; panował 1180-1185; Magill 881-883).

55 Pałac w Fukuharze był główną siedzibą Taira Kiyomori.
} 
no jintō wo miru zu (Taira Kiyomori widzący setki ludzkich czaszek w Fukuharze, 1890). Wszystkie te drzeworyty świadczą o nawiązaniu do bardzo plastycznego opisu z Heike monogatari56 (Opowieść o rodzie Taira; XIII wiek):

Pewnego ranka wielki minister ${ }^{57}$ zszedł z chōdai ${ }^{58}$, otworzył drewniane drzwi i wyjrzał na zewnątrz. Kiedy jego wzrok padł na dziedziniec, zobaczył lawinę nagich czaszek zasypujących jego ogród po same brzegi. Gdzie tylko spojrzeć, w górę czy w dól, wypełniały całą przestrzeń. Staczały się, trącały o siebie i spychały na boki, klekocząc przy tym tak głośno, że Taira Kiyomori zawołał: - Jest tu ktoś? Jest tu ktoś? - lecz niestety nikt się nie pojawił. Kiedy tak stał, większość czaszek skupiła się w jednym miejscu i uformowała jedną wielką jak góra czachę. Miała czterdzieści, czterdzieści pięć metrów wysokości i była tak ogromna, że nie mogła się zmieścić na dziedzińcu. Tkwiły w niej setki tysięcy dużych par oczu, które jak żywe patrzyły gniewnie na wielkiego ministra nie spuszczając z niego wzroku nawet na mrugnięcie. Mnich nie pokazując zaskoczenia, twardo spojrzał na zjawę. Pod jego silnym spojrzeniem zjawa zniknęła bez śladu, jak tylko promienie słońca dotknęły zamarzniętej rosy (Heike monogatari, źródło elektroniczne) $)^{59}$.

Duchy te tradycyjnie interpretuje się jako mściwe dusze klanu Minamoto60, z którym ród Taira rywalizował o wpływy i władzę (Isao 88). Duchy żywiące pragnienie zemsty (onryō - dosł. mściwe duchy ${ }^{61}$ ) jako istoty nadprzyrodzone zaczęły

56 Heike monogatari to opowieść wojenna, która przedstawia dziewięćdziesiąt lat (1131-1221) historii powstania i upadku rodu Taira. W języku japońskim istnieje możliwość odczytywania terminów na sposób japoński oraz chiński, „Heike” jest tutaj chińskim odczytaniem „Taira”. Najpopularniejsza wersja z ok. 1240 roku składa się z dwunastu ksiąg i epilogu. Główne wydarzenia opisują okres od przejęcia władzy przez Tairę Kiyomoriego (1167) do rozbicia wojsk rodu Heike pod Dannourą (1185). Głównymi motywami są los przegranych, nietrwałość ludzkiego życia oraz zapłaty za swoje czyny (jap. Ingaōhō, Melanowicz 137).

$57 \mathrm{~W}$ oryginale nyūdō shōkoku. Tytuł ten wskazuje na wielkiego ministra, który został buddyjskim mnichem.

${ }^{58}$ Chōdai to podwyższona przesłonięta zasłonami platforma, która służyła do spania. Korzystali $\mathrm{z}$ niej ludzie o wysokiej randze społecznej.

59 Tłumaczenie własne ze starojapońskiego.

${ }^{60}$ Klan Minamoto był głównym wrogiem polityczno-militarnym rodu Taira. Podczas zamieszek w 1159 roku zginęli wszyscy z głównej linii rodu Minamoto z wyjątkiem Minamoto Yoritomo (11471192) i jego brata Minamoto Yoshitsune (1159-1189), którzy zostali wygnani. Przegrany klan stracił swoje wpływy na dworze cesarskim. Odzyskał je w 1180 roku podczas wojny wewnętrznej przeciwko rodowi Taira. Wkrótce potem Minamoto no Yoritomo ustanowił pierwszy w Japonii system rządów militarnych bakufu i został pierwszym w historii siogunem (Magill 881-883).

${ }^{61}$ Jednym z najbardziej pamiętliwych onryō był Sugawara Michizane (845-903), potężny polityk i mistrz kaligrafii, który w wyniku spisku swoich rywali został zesłany na południe kraju, gdzie umarł w samotności. Po jego śmierci piorun uderzył w pałac cesarski, a stolica była nękana plagą, suszą i powodzią. W niewyjaśnionych okolicznościach zmarli też wrogowie mściwego polityka. Aby przebłagać jego ducha, został on deifikowany jako opiekun nauki (Hori 115). 
pojawiać się w kronikach na przełomie VIII i IX wieku. Ich źródła można dopatrywać się we wspomnianej wcześniej koncepcji duszy yin duszy yang. Z początku postrzegano je jako mściwe duchy arystokratów, którzy zginęli w wyniku intryg politycznych i wrócili, aby odpłacić się swoim wrogom (Hori 71). Przypisywano im wiele nieszczęśliwych wypadków, w tym klęski żywiołowe. Wierzono, że dopiero w specjalnej ceremonii, w wyniku której gniewne onryō stawały się szlachetnymi goryō (szlachetne duchy), dochodziło do przebłagania duchów (Tubielewicz 2001: 163). Koncepcja ta uległa zmianie pod wpływem buddyjskiej idei równości. Onryō zostały przeinterpretowane i każdy człowiek, bez względu na status społeczny, mógł wrócić jako mściwy duch, o ile na łożu śmierci wyraził chęć dokonania zemsty lub zmarł w wyniku przypadkowej śmierci $w$ niezwykłych okolicznościach (Hori 43). Na tej podstawie można stwierdzić, że $w$ przytoczonym fragmencie ludzkie czaszki utożsamiono $\mathrm{z}$ duszami zmarłych. $\mathrm{W}$ tym przypadku szkielet wydaje się dramatyczną wizualizacją onryō. Łączy on niepokój oczekiwania na zemstę ze strachem przed śmiercią i kontaktem z ludzkimi szczątkami. Wariację na temat mściwych duchów przyjmujących postać szkieletu można znaleźć na drzeworycie Katsushiki Hokusaia pt. Kohada Koheiji ${ }^{62}$ (Kohada Koheiji, 1831). Dzieło to przedstawia scenę, w której tytułowy bohater podnosi swoim kościstym palcem zasłonę i przygotowuje się do zemsty nad zdradliwą żoną i jej kochankiem, którzy go zamordowali (Kabat 213-215). Kohada Koheiji nie jest tu w pełni szkieletem, fragmenty skóry i mięśni jeszcze trzymają się kości, co nie dość, że dodaje całej scenie makabryczności, to jeszcze może świadczyć o pośpiechu, z jakim zmarły chciał pomścić swoją śmierć. Motyw zemsty pojawia się także w Sōma no furudairi (W Starym pałacu cesarskim w Sōmie, 1844) autorstwa Utagawy Kuniyoshiego (1797-1862). W tym przypadku ogromny szkielet został wezwany ze świata nadprzyrodzonego przez księżniczkę63, jako narzędzie zemsty i siły. Miał on pomścić śmierć jej ojca i zabić mężczyzn, którzy wtargnęli do zamku (Ōta Kinenbi Bijutsukan 249). Szkielet został potraktowany jako yōkai. Można interpretować go jako niespokojne dusze, które przybrały tę formę, aby wzbudzić strach w przeciwniku.

Chociaż czaszka w większości przypadków kojarzyła się ze śmiercią, nie zawsze była źródłem negatywnej energii. W najstarszym zbiorze krótkich opowiadań

${ }^{62}$ Kohada Koheiji był postacią z opowiadania Santō Kyōdena (1761-1816), pt. Fukushū kidan Asaka numa (Dziwna historia o zemście znad bagien w Asace,1803).

${ }^{63}$ Księżniczka Takiyasha była córką Tairy Masakado (?-940), wywodzącego się z linii Cesarza Kammu (737-806; panował 781-806), który osiadł na prowincji we wschodniej Japonii. Poprowadził on bunt Jōhei Tengyō no ran (bunt ery Jōhei-Tengyō; 939-940) przeciwko władzy centralnej i nazwał siebie nowym cesarzem. Ostatecznie został złapany i zginął przez ścięcie głowy. Drzeworyt przedstawia scenę z legendy, według której wysłannicy prawowitego władcy wpadli do rezydencji Masakado w Sōmie w celu znalezienia pozostałych konspiratorów. Księżniczka Takiyasha w samoobronie wezwała na pomoc ogromny szkielet (Reeve 129). 
buddyjskich Nihonryōiki (Japońska księga o duchach i dziwach, 787-824) zapisano dwie historie o zwykłych ludziach, którzy bezwiednie pomogli zbłąkanemu duchowi. W jednej $\mathrm{z}$ nich mnich przeniósł deptaną przez zwierzęta i podróżnych czaszkę, w drugiej - rolnik wyjął gałązkę bambusa z oczodołu, która sprawiała ból za każdym razem, gdy zawiał wiatr (Nagata 60-61, 319-323). W obu przypadkach ukazały się im postaci zmarłych, którzy opowiadają historię swojego morderstwa. $\mathrm{W}$ ramach spłaty długu wdzięczności śmiertelnicy zostali nagrodzeni. Z kolei w podobnym, ale późniejszym zbiorze opowieści dydaktycznych Konjaku monogatarish $^{64}$ (Opowieści z dawnych czasów, XI wiek) czaszka różowym, nienaruszonym rozkładem językiem recytowała sutry (Mabuchi 236-239, 319-320). Można to interpretować jako podkreślenie magicznej mocy sutry. Jeśli recytowana poprawnie i nieprzerwanie, mogła się wryć w umysł, serce a nawet kości recytującego. Słowa nie przestawały być wymawiane nawet po śmierci, co objawiało się w tym nadprzyrodzonym zjawisku (Eubanks 159). Być może motywem tym próbowano pokazać głębokie oddanie zmarłej osoby oraz przekonać czytelników, że buddyjskie sutry miały moc animowania i oczyszczania nawet skalanych ludzkich kości i mogły je zmienić w coś świętego. Kontrast pomiędzy czystością i nieczystością pojawił się w rysunku tuszem Maruyamy Ōkyo (1733-1795) Hashō hakkotsu zazen zu (Szkielet praktykujący zazen ${ }^{65}$ na falach, 1787). Zazen uważano za rytuał oczyszczający duszę i ciało. Praktykowano go w celu uwolnienia się od pragnień świata doczesnego i nieczystości ciała - innymi słowy od wszystkiego, co symbolizował szkielet. Artysta podkreślił to falami wody, która w japońskiej tradycji religijnej ma działanie puryfikujące (Fuchūshi Bijutsukan 78). W obu przypadkach rytuały oczyszczające zestawione $\mathrm{z}$ nieczystym ludzkim ciałem prawdopodobnie miały podkreślać wielką moc wierzeń.

W kolejnym przykładzie, również zakorzenionym w buddyzmie, choć pojawiają się szkielety, uwagę skupiono głównie na żywych. Rozważania dotyczą Ikkyū gaikotsu (Szkielety Ikkyū, 145766), czyli zwoju łączącego elementy poezji, prozy i grafiki. Za domniemanego autora uważa się buddyjskiego mnicha Ikkyū Sōjuna (1394-1481) z Kioto. Prawdopodobnie napisał on to dzieło w niezwykle trudnym czasie, kiedy Japonię nawiedzały silne trzęsienia ziemi, pożary, klęski głodu i epidemie. Na dodatek kraj był pogrążony w wojnach wewnętrznych,

${ }^{64}$ Jedyna historia ze zbioru Nihonryōiki (zwój trzeci, opowieść pierwsza) o czaszce z różowym językiem została powtórzona w późniejszym Konjaku monogatarishū, w którym motyw ten pojawia się w kilku niezależnych opowieściach.

${ }^{65}$ Zazen, czyli siedząca medytacja, ma swoje korzenie w buddyzmie zen. Polega ona na medytacji $\mathrm{w}$ cichym pomieszczeniu w odpowiedniej pozycji siedzącej i kontroli oddechu. Celem praktyki jest osiągnięcie stanu, w którym myśli swobodnie przepływają przez umysł medytującego. Największym propagatorem zazen w Japonii był mnich Dōgen (1200-1253), założyciel szkoły Zen Sōtō (Tubielewicz 1996: 351).

66 Prawdopodobna data pierwszego wydania. 
a ulice były wyściełane trupami (Franck 69). Możliwe jest, że horrory dnia codziennego zainspirowały mnicha do zmierzenia się z tematem śmierci (Franck 70). Bohaterem zwoju jest kapłan, który we śnie widzi szkielety naśladujące ludzkie zachowania, jak gdyby wciąż żyły. Pomiędzy nim a jednym ze szkieletów zawiązuje się konwersacja, którą można interpretować niczym pretekst do wyrażenia obserwacji filozoficznych na temat znaczenia życia i śmierci. Ikkyū Sōjun utrzymuje swoje dzieło w stylu dydaktycznym. Krytykuje ludzi, nawet mnichów, za ich nadmierne zainteresowanie bogactwem, dobrami ziemskimi i podkreśla bezcelowość takiego przywiązania do przemijającego świata (Franck 78). Bohater wyjawia także, że śmierć może się wydawać daleka, ale w rzeczywistości każdy z nas pod skórą już jest szkieletem (Franck 72-75). Ze względu na takie uwagi można skłaniać się ku interpretacji, że narysowane $\mathrm{w}$ zwoju kościotrupy przedstawiają raczej żywych odartych ze skóry i mięśni niżeli ożywione szczątki umarłych. Niezależnie od zwoju, motyw szkieletów naśladujących życie ludzi pojawił się także na drzeworytach Kawanabe Kyōsaia (1831-1889). Obie części Gaikotsu no seikatsu zu (Życia szkieletów, 1881) są wypełnione ponad dwudziestoma szczegółowymi portretami szkieletów, które piją, jedzą, tańczą, walczą, świętują, kaligrafują, grają na instrumentach... Prawdopodobnie artysta próbował ukazać rożne stany emocjonalne, choć należy wziąć pod uwagę, że był on uważany za mistrza przedstawiania szkieletów i mogły być to studia nad nimi (Kyōgoku 141-143). Inna interpretacja wskazuje na charakter samego gatunku drzeworytów w roli źródła rozrywki. W języku japońskim grzechoczące kości wydawały dźwięk kata kata, który był uważany za bardzo śmieszny. Im więcej szkieletów, tym ten dźwięk miał być w ludzkiej wyobraźni głośniejszy. Dzieło Kawanabe mogło nie tyle przerażać, co łagodzić strach przez zmuszenie widzów do śmiechu (Kabat 213-215).

Generalizując, stosunek Japończyków do śmierci można określić w głównej mierze jako negatywny, jednak należy zauważyć, że pojawiały się przejawy pozytywne. Pustkę po odrzuceniu śmierci cielesnej wypełniono rozbudowanym światem nadprzyrodzonym, w którym ludzka czaszka była śladem po przeszłym życiu danej osoby. Funkcjonowała jako medium, dzięki któremu zmarły mógł opowiedzieć koleje swojego losu. Oznacza to, że co najmniej od VIII wieku zwłoki lub ich fragment był kojarzony z duchami zmarłych. Obok nich istniały też zjawy o mściwych intencjach, budzące powszechny strach. Objawiały one swoją obecność głównie pod postacią klęsk żywiołowych, które miały oddawać pełnię rządzących nimi negatywnych emocji. Można powiedzieć, że kulminacją wyobrażeń o gniewnych duchach była przytoczona scena z Tairą Kiyomorim w Heike monogatari. Pojedyncze czaszki złączyły się $\mathrm{w}$ jedną, symbolizującą skumulowaną nienawiść rodu Minamoto do rodu Taira. Nie była to już zemsta o szerokim zasięgu, ale bardziej skierowana na indywidualną osobę, uważaną za przyczynę nieszczęścia zmarłego. Sposobem na pomszczenie swoich krzywd było torturowanie winnego przerażającymi wizjami. Przekonanie o istnieniu mściwych duchów znalazło swo- 
je odzwierciedlenie w sztuce drzeworytnictwa w XVIII i XIX wieku, kiedy rolę mściciela zza grobu przejął ludzki szkielet, stając się jednocześnie postacią widzianą nie tylko przez ofiarę.

Może się wydawać, że w przedstawionym okresie od VIII wieku do XVIII wie$\mathrm{ku}$ graficzne wyobrażenia dotyczące szkieletu nie rozkwitły tak bardzo jak w Europie Zachodniej. Należy jednak wziąć pod uwagę, że japoński proces asocjacji zwłok $\mathrm{z}$ duchami zmarłych przebiegał $\mathrm{w}$ miarę równolegle do tego europejskiego i stopniowo ewoluował pod wzajemnym wpływem shintō i buddyzmu. Tu również udało się zaobserwować przejście od strachu przed ogólną obecnością śmierci - mściwych duchów do obaw przed zindywidualizowaną formą śmierci - onryō z osobistym celem swojej zemsty. Ugruntowanie się zespołu powyższych wierzeń oraz ich ewentualne zmiany trwały jednak dłużej niż na Zachodzie, ponieważ przełomowy moment jakim było odkrycie wnętrza ludzkiego ciała na nowo miał miejsce o około dwieście lat później niż w Europie.

\section{Znaczenie kości - konkluzje}

W Europie Zachodniej i Japonii, choć w odstępie ponad dwustu lat, podobne odkrycia medyczne wpłynęły na pojawienie się ruszającego szkieletu $\mathrm{w}$ sztuce. W omawianych przypadkach stał się on postacią wyróżniającą w symbolice śmierci. Choć w obu kulturach pojawiły się koncepcje takie, jak niewidzialna dusza, podział na duszę i ciało, możliwość rezurekcji, rozróżnienie na śmierć naturalną i nagłą czy duchy zmarłych pozostające na ziemi, powstały one pod wpływem lokalnych tradycji i wierzeń, z których wyniknęły poniższe różnice.

Pierwsza rozbieżność dotyczy percepcji szkieletu w relacji do wierzeń dotyczących śmierci i religii. Prawdopodobnie i w chrześcijańskiej Europie, i w Japonii szkielet był traktowany jako namacalny dowód na to, co działo się z ludzkim ciałem po śmierci. W przeciwieństwie do Japończyków chrześcijanie odrzucili ideę nieczystości zwłok. Przede wszystkim wynikało to z obecności kultu ciała Jezusa oraz świętych ${ }^{67}$. Ich szczątki, a nawet fragmenty były uznawane za źródło nad-

${ }^{67} \mathrm{~W}$ japońskim buddyzmie również istniał kult relikwii, jednakże dotyczył on głównie szczątków Buddy. Idea upamiętniania ludzi, którzy poświęcili swoje życie dla dobra została zaadoptowana przez arystokrację ok. II poł. VII wieku. W tym celu budowano stupy i umieszczano w nich szczątki szanowanych osób lub magiczne zaklęcia. Od $\mathrm{X}$ wieku wzrósł jednak strach związany $\mathrm{z}$ onryō i arystokracja zaczęła budować dla upamiętnienia zmarłych stupy, jednakże głównie w celu własnej ochrony przed gniewem niewidzialnego wroga. Dydaktyczna literatura okresu Heian wspomina o oddawaniu czci szczątkom jako sposobie na zapewnienie sobie lepszego życia w zaświatach lub na uzyskanie nagrody $\mathrm{w}$ doczesnym życiu (zdrowie, zmiana wyglądu, etc.). Można powiedzieć, że podobnie jak w Europie istniała pewna więź pomiędzy szczątkami zmarłego a żywymi, jednakże nie była ona na tyle silna, aby wyprzeć przekonanie o istnieniu kegare, czy onryō. Więcej w B. O. Ruppert. 
przyrodzonej mocy i ochrony (Park 35). W Japonii negatywny stosunek do zwłok był podtrzymywany przez setki lat i dopiero w 1872 roku zniesiono prawo dotyczące kegare. Do tego czasu śmierć traktowano jak chorobę, którą można się zarazić przez bezpośredni kontakt ze zwłokami. Doprowadziło to do tego, że grupy zawodowe zajmujące się śmiercią zostały wyrzucone poza obręb społeczeństwa, a całe ich rodziny oraz przyszli potomkowie byli uważani z natury za nieczystych.

$\mathrm{W}$ obu przypadkach religie o największych wpływach kształtowały percepcję ludzkich zwłok. Można stwierdzić, że chrześcijańscy i buddyjscy duchowni wykorzystali niski poziom wiedzy na temat śmierci, aby wpłynąć na zachowanie wiernych. Za pomocą ludzkich kości próbowano przekonać odbiorców, że jedynym remedium na strach były właściwe dla danej religii rytuały. Pomimo różnic w realizacji, makabryczne portrety szczątków funkcjonowały jako ostrzeżenie przed pułapkami przemijającego materialnego świata. W Europie Kościół podkreślał konieczność odpowiednich przygotowań zanim umierający pożegnał się ze światem doczesnym. Towarzyszyły temu kazania wypełnione symboliką memento mori i ich wizualizacje pod postacią różnych motywów artystycznych. Podkreślały one los wspólny dla wszystkich bez względu na status społeczny i materialny. Dzięki temu śmierć stała się ostatecznym niwelatorem różnic społecznych. Natomiast w Japonii podobną funkcję dydaktyczną pełniło buddyjskie „Dziewięć etapów rozkładu", jednakże ukazywały one nieczystość całej cielesności. Przesłanie o równości ludzi pojawiło się także w Szkieletach Ikkyū, ale autor przedstawił ten temat w szerszej perspektywie. Mnich podkreślał, że wszyscy ludzie są tacy sami i za życia i po śmierci. Dla porównania w danse macabre to śmierć, siła z zewnątrz, odzierała ludzi ze statusu i bogactwa, czyniąc ich równymi. $W$ obu przypadkach zawarto jasny przekaz, że szkieletem zostanie każdy z nas, ale w koncepcji europejskiej ludzkie szczątki nie pozostały tylko leżącymi w bezruchu śladami czyjejś egzystencji. Zmarli poprzez rozkładające się ciało wchodzili w interakcje z żywymi: pouczali i tańczyli. Japońscy zmarli, choć związani ze swoimi szczątkami ( $\mathrm{w}$ przedstawionych $\mathrm{w}$ artykule opowiadaniach) odgrywali swoją rolę $\mathrm{w}$ ludzkiej postaci. Można stwierdzić, że chrześcijańscy umarli otrzymali głos tak samo jak japońskie duchy, ale przez ich ożywione ciała przemawiała śmierć.

Druga rozbieżność między Japonią a chrześcijańską Europą dotyczy interpretacji szkieletu jako istoty nadprzyrodzonej. $W$ obu kulturach szkielet jako jeden z ostatnich etapów rozkładu był utożsamiany ze zmarłymi. W nim mogła zamieszkać dusza osoby, która zmarła niegodnie - nagle lub w niewyjaśnionych okolicznościach. Szkielet zyskał nowe znaczenie dopiero z chwilą, gdy zaczął się poruszać. W Europie Zachodniej po okresie, w którym kontrastowano życie i śmierć przez zestawienie ciała żywego z martwym, abstrakcyjna śmierć stała się

"Considering Relic Veneration in Medieval Japan" Death and the Afterlife in Japanese Buddhism. Red. J. I. Stone, M. N. Walter. Honolulu: University of Hawaii Press, 2009. S. 102-136. 
konkretną postacią - Śmiercią. W procesie laicyzacji zyskała ona ludzkie cechy i pragnienia, jak gdyby sama tęskniła do życia, które miała zabrać. Chociaż była całkowitym przeciwieństwem egzystencji, jako osoba była bardzo podobna do ludzi. Można powiedzieć, że szkielet stał się personifikacją śmierci. W Japonii szkielet był domeną duchów zmarłych. Były one związane ze swoimi zwłokami na tyle mocno, że mogły odczuwać ich ból (bambus w oczodole, deptanie) oraz modlić się. Jednakże sam zmarły pojawiał się w swojej ludzkiej postaci, nawet $\mathrm{z}$ dala od szczątków. Oprócz dusz czekających na pomoc żywych oraz przodków chroniących swoich potomków, istniały także te o mściwej naturze. Z początku komunikowały się one z ludźmi przez zsyłanie klątw, ale w końcu przybrały bardziej jednoznaczną formę, jak w Heike monogatari. Postać szkieletu była reprezentacją zmarłych dusz, które zostały, aby dopełnić zemsty. Mogły one dręczyć, a nawet zabijać. Śmierć zadana $\mathrm{w}$ ten sposób była wynikiem osobistej zemsty ducha na ludziach winnych jego nieszczęścia, sposobem na osądzenie kogoś za jego czyny wbrew naturalnej kolei rzeczy. Europejska Śmierć dręczyła swoje ofiary, ale nie potępiała ich. Jej celem nie była indywidualna osoba, ale cała ludzkość. W Europie liczne portrety Śmierci jako szkieletu wpłynęły na ugruntowanie się tej personifikacji, w Japonii natomiast częste malowanie magicznych postaci sprawiło, że straciły one na wiarygodności. Dzięki temu, że artyści nadali im twarze i portretowali je w zabawnych sytuacjach, mieszkańcy świata nadprzyrodzonego stracili swoją moc i odeszli do świata fikcji (Kabat 16).

\section{Zakończenie}

W zanalizowanych kręgach kulturowych $\mathrm{w}$ celu zmierzenia się ze śmiercią i stworzenia mechanizmu obronnego zwrócono się do świata nadprzyrodzonego. Miało to pomóc odnaleźć wspólnotom ludzkim spokój w pełnej niepokojów egzystencji. Nastroje niepewności i strachu o życie wzmocnione przez okresy klęsk żywiołowych zostały wykorzystane przez główne religie, które próbowały spopularyzować własne idee i wartości w zdominowanych uczuciem kruchości życia czasach. Wpływ instytucji religijnych można zaobserwować w sposobie percepcji ludzkiego ciała. W chrześcijaństwie ludzkie zwłoki traktowano z szacunkiem, nie uważano ich za skalane. Wręcz przeciwnie - szczątki świętych były źródłem pozytywnej nadprzyrodzonej mocy, która mogła przynieść wierzącym łaski. Można powiedzieć, że Europejczycy mieli raczej pozytywny stosunek do ciała i interesowali się nim, o czym świadczą badania i odkrycia anatomiczne oraz sztuka, którą one zainspirowały. Akceptacja ludzkiej cielesności zakorzeniona była być może w niektórych poglądach antyku, kiedy ciało kultywowano nie tylko odnośnie atletyzmu, ale traktowano je także jako naczynie dla duszy, które było narażone na 
czynniki zewnętrzne i należało je chronić (DuBois 109)68. Z kolei w Japonii martwe ciało, a w niektórych nurtach buddyjskich nawet żywe, traktowano jako nieczyste. Czaszka i szkielet symbolizowały śmierć fizyczną i mogły być źródłem zarówno szczęścia, jak i nieszczęścia, ale mimo wszystko najczęściej pojawiały się one w kontekście przerażających mściwych duchów, co dobrze korespondowało z obowiązującym tabu śmierci.

Największe różnice pomiędzy europejskim i japońskim sposobem przedstawiania szkieletu leżą $w$ interpretacji jego nadprzyrodzonych mocy. Na Zachodzie kościotrup był nie tylko kojarzony z fizyczną śmiercią, ale stał się jej personifikacją - Śmiercią. Wyobrażano go sobie jako zewnętrznego, czyli obiektywnego zbieracza ludzkich dusz. Śmierć uformowana na wzór suchego ludzkiego szkieletu była łatwo rozpoznawalna, a jej wyjątkowość objawiła się w przestrzeni artystycznej i kreatywnych interpretacjach Śmierci-osoby. Artyści konfrontowali Śmierć z takimi wartościami jak miłość, młodość, piękno, co miało wzmóc makabrę, połączenie czarnego humoru i groteski (Kurtz 225).

W Japonii kościotrup jako postać nadprzyrodzona pojawił się w różnych źródłach literackich, ale dopiero w XVIII i XIX wieku stał się widzialny i zaczął być czymś więcej niż leżącymi na ziemi w bezruchu ludzkimi kośćmi. Można stwierdzić, że został on odarty z negatywnych skojarzeń dopiero pod wpływem kultury zachodniej. Zainspirowani europejską anatomią artyści wprowadzili szkielet jako widzialną postać do sztuki popularnej. Szkielet był kształtem, który jasno wskazywał na nieszczęśliwą naturę ducha, ale jego intencje różniły się w zależności od opowiadania. Nie uważano go za Śmierć, był on z nią związany. Artyści zestawiali go z pięknem i ciepłem żywych istot (Ōta Kinenbi Bijutsukan 254).

Wydaje się, że szkielet $\mathrm{w}$ naturalny sposób stał się częścią symboliki śmierci. $\mathrm{Na}$ pewnym etapie rozwoju cywilizacji powszechną wiedzą było to, że ludzkie kości to jedno z ostatnich stadiów rozkładu i przyszłość każdego żywego. Inspiracja odkryciami anatomicznymi i proces włączenia ich do sztuki był odważnym sposobem dokonywania refleksji nad naturą życia i śmierci, ciała i zwłok oraz widzialnych i niewidzialnych aspektów ludzkiej egzystencji. Europejczykom proces ten pomógł ujarzmić abstrakcyjną ideę umierania i zaakceptować śmierć jako nieodłączną towarzyszkę. Natomiast Japończycy uważali go za spotkanie oko w oko $\mathrm{z}$ tym, czego bali się od stuleci.

\section{BIBLIOGRAFIA}

Aberth, John. From the Brink of the Apocalypse: Confronting Famine, War, Plague, and Death in the Later Middle Ages. New York: Psychology Press, 2013.

68 Problem cielesności w kulturze europejskiej został szeroko opisany w serii L. Kalof et al. (red.). A Cultural History of the Human Body 1-6. Oxford: Berg Publishers, 2010. 
Applebaum, Wilbur. Encyclopedia of the Scientific Revolution from Copernicus to Newton. New York: Routledge, 2008.

Ariès, Philippe. Images of Man and Death. Tłum. Janet Lloyd. Cambridge, Massachusetts, London: Harvard University Press, 1985.

Ariès, Philippe. Człowiek i śmierć. Warszawa: Wydawnictwo Aletheia, 2011.

Bätschmann Oskar, Griener Pascal. Hans Holbein: Revised and Expanded Second Edition.London: Reaktion Books. 2014

Binski, Paul. Medieval Death. Ritual and Representation. London: British Museum Press, 1996.

Bowers, John Z. Nihon ni okeru seiyō igaku no senkushatachi [Pionierzy zachodniej medycyny w Japonii]. Tłum. Takuya Kanehisa, Tomoyoshi Kashima. Tōkyō: Keiōgijuku Daigaku Shuppankai, 1998.

Broomhall, Susan. "The Body in/as Text: Medical Knowledge and Technologies in the Renaissance". A Cultural History of the Human Body in the Renaissance. Red. L. Kalof. Oxford: Berg, 2010. S. 73-98.

Burke, Linda. The book of gladness. Le livre de Leesce: a 14th century defense of women, in English and French. Jefferson, North Carolina: McFarland and Company Inc., 2013.

Byrne, Joseph P. Encyclopedia of the Black Death. Santa Barbara, Denver, Oxford: ABC-CLIO, 2012.

Cheney, Liana (red.). The Symbolism of Vanitas in the Arts, Literature, and Music. Comperative and Historical Studies, Lewiston, N.Y. : Edwin Mellen Press, 1989.

Clark, James M. The Dance of Death. In the Middle Ages and the Renaissance. Glasgow: Jackson, Son \& Company, 1950.

DuBois, Page "Popular Beliefs about the Human Body in Antiquity". A Cultural History of the Human Body in Antiquity. Red. D.H. Garrison. Oxford: Berg, 2010. S. 107-132.

Ebersole, Gary L. Ritual poetry and the politics of death in early Japan. Princeton, N.J: Princeton University Press, 1992.

Eubanks, Charlotte. Miracles of Book and Body: Buddhist Textual Culture and Medieval Japan. Berkeley: University of California Press, 2011.

Franck, Frederick (red.) "Ikkyū's skeletons”. The Buddha Eye: An Anthology of the Kyoto School and Its Contemporaries. Bloomington: World Wisdom, 2004.

Fuchūshi, Bijutsukan (red.). Edo no jinbutsuga: sugata no bi, chikara, ki [Portrety z okresu Edo: piękno, siła i dziwy]. Tōkyō: Kyūryūdō, 2010.

Gertsman, Elina. The Dance of Death in the Middle Ages. Image, Text, Performance. Turnhout: Brepols Publishers, 2010.

Gottfried, Robert S. The Black Death: Natural and Human Disaster in Medieval Europe. New York: Free Press, 1985.

Guthke, Karl S. The Gender of Death. A Cultural History in Art and Literature. Cambridge: Cambridge University Press, 1999.

„Heike monogatari”. Web. 13.09.2015. <http://www.manabu-oshieru.com/daigakujuken/ kobun/ heike/05/0301.html>

Holbein, Hans. Dance of Death and Bible Woodcuts. New York: The Sylvian Press, 1947.

Honda, Toyotomi. Edo no Hinin [Hinin w Edo]. Tōkyō: 31 Shobō, 1992.

Hori, Ichiro. Folk Religion in Japan. Continuity and Change. Chicago: University of Chicago Press, 1983.

Isao, Toshiko (red.). Kuniyoshi Yōkai Hyakkei [Sto przedstawień postaci nadprzyrodzonych Kuniyoshiego]. Tōkyō: Kokushokankōkai, 2001.

Ishida, Sumio (red.). Rangaku no haikei [Okoliczności rozwoju rangaku]. Kyōto: Shibunkaku, 1988.

Ishida, Sumio (red.). Oranda ni okeru rangakuisho no keisei [Powstawanie opracowań medycznych rangaku w Holandii]. Kyōto: Shinbunkaku, 2007.

Johnson, Marguerite. "Marked Bodies: Divine, Human, and Bestial". A Cultural History of the Human Body in Antiquity. Red. D.H. Garrison. Oxford: Berg, 2010. S. 185-216. 
Johnson Noble, John. The Life of Thomas Linacre, Doctor in Medicine: Physician to King Henry VIII, the Tutor and Friend of Sir Thomas More. London, 1835.

Kabat, Adam. Edo bakemono sōshi [Postaci nadprzyrodzone z Edo]. Tōkyō: Shōgakukan, 1999.

Kalof, Linda et al (red.). A Cultural History of the Human Body 1-6. Oxford: Berg Publishers, 2010.

Kanert, Maciej. Buddyzm japoński. Jego polityczne i społeczne implikacje w okresie 538-645. Warszawa: Wydawnictwo TRIO, 2005.

Katsuda, Itaru. Shishatachi no chūsei [Średniowiecze zmarłych]. Tōkyō: Kichikawa Kōbunkan, 2003.

Keene, Donald. The Japanese Discovery of Europe 1720-1830. Stanford, California: Stanford University Press, 1969.

Komatsu, Kazuhiko (red.). Nihon yōkaigaku taizen [Japońskie postaci nadprzyrodzone. Dzieła zebrane]. Tōkyō: Shōgakukan, 2003.

Kotański, Wiesław. Kojiki czyli kronika dawnych zdarzeń. Warszawa: Państwowy Instytut Wydawniczy, 1975.

Kurtz, Leonard P. The Dance of Death and the Macabre Spirit in European Literature. New York: Institute of French Studies, Inc. Columbia University, 1934.

Kyōgoku, Natsuhiko (red.). Kyōsai Hyakkei [Sto przedstawień Kyōsaia]. Tōkyō: Kokushokankōkai, 1998.

Melanowicz, Mikołaj. Historia literatury japońskiej. Warszawa: Wydawnictwo Naukowe PWN 2011.

Mabuchi, Kazuo. Konjaku monogatari. Tōkyō: Shōgakukan, 1999.

Magill, Frank N. (red.). Dictionary of World Biography. Volume 2: The Middle Ages. London and New York: Routledge, 1998.

McTavish, Lianne. "Birth and Death in Early Modern Europe". A Cultural History of the Human Body in the Renaissance. Red. L. Kalof. Oxford: Berg, 2010. S. 15-36.

Muir, Lynette R. The Biblical Drama of Medieval Europe. Cambridge: Cambridge University Press, 2003.

Nagata, Naori. Nihonryōiki [Japońska księga o duchach i dziwach]. Tōkyō: Shōgakukan. 1995.

Nagasawa, Kōshō. Sankotsu ha, subekidenai. Maisō no rekishi kara [Nie wolno rozrzucać prochów. Z perspektywy historii pochówków]. Tōkyō: Kōdansha Bijinesu Pātonāzu, 2012.

Nakagawa, Manabu. Kinsei no shi to seiji bunka. Narimono Teishi to kegare [Kultura śmierci i polityki w nowożytności. Zakaz dźwięku a nieczystość]. Tōkyō: Yoshikawa Kōbunkan, 2009.

Nakamura, Teiri. Seimeikan no nihonshi. Kodai, Chüsei hen [Japońska historia poglądu na życie. Starożytność i średniowiecze]. Tōkyō: Nihon Editāzukūru, 2011.

Niwa, Motoji. Ohaka no hanashi [O grobach]. Tōkyō: Kawade Shodoshinsha, 1992.

O' Malley, C.D. Andreas Vesalius of Brussels 1514 - 1564. Berkeley and Los Angeles: California University Press, 1964.

Osler, William. Thomas Linacre: Linacre Lecture, 1908. Cambridge: Cambridge University Press, 2014.

Ōta, Kinenbi Bijutsukan. Utagawa Kuniyoshi. Tokyo: NHK Promotion, 2011.

Park, Katharine. "Birth and Death". A Cultural History of the Human Body in the Medieval Age. Red. L. Kalof. Oxford: Berg, 2010. S.17-38.

Raber, Karen. "The Common Body: Renaissance Popular Beliefs". A Cultural History of the Human Body in the Renaissance. Red. L. Kalof. Oxford: Berg, 2010. S. 99-124.

Reeve, John. Japanese Art in Detail. Harvard University Press: Cambridge, 2005.

Reinburg, Virginia. French books of hours: makicg an archive of prayer, c. 1400-1600. Cambridge New York: Cambridge University Press, 2012.

Ruppert, Brian O. "Considering Relic Veneration in Medieval Japan". Death and the Afterlife in Japanese Buddhism. Red. J.I. Stone, M. N. Walter. Honolulu: University of Hawai'i Press, 2009. S. 102-136.

Salmón, Fernando 2010. "The Body Inferred: Knowing the Body through the Dissection of Texts". A Cultural History of the Human Body in the Medieval Age. Red. L. Kalof. Oxford: Berg, 2010. S. 77-98. 
Scheid, Bernhard. "Overcoming Taboos on Death: The Limited Posibilities of Discourse on the Afterlife in Shinto". Practicing the Afterlife: Perspectives from Japan. Red. S. Formanek. Wien: Österreichische Akademie der Wissenschaften, 2004. S. 205-230.

Shinbo, Satoru. Nihonjin no shiseikan. Nihonbunka no konpon o motomete [Japońskie poglądy na życie i śmierć. W poszukiwaniu źródeł japońskiej kultury]. Okayama: Daigaku Kyōikushuppan, 2009.

Schuster, Eva (red.). Taniec śmierci: od późnego średniowiecza do końca XX wieku. Szczecin: Zamek Książąt Pomorskich, 2002.

Screech, Timon. Edo no shintai wo hiraku. Tłum. Takayama Matsuo. Tōkyō: Sakuhinsha, 1997.

Stone, Jacqueline I. "Dying Breath: Deathbed Rites and Death Pollution in Early Medieval Japan". Heroes and Saints: The Moment of Death in Cross-Cultural Perspectives. Red. P. Granoff, K. Shinohara. Newcastle: Cambridge Scholars Publishing, 2007. S. 173-246.

Sugimoto, Tsutomu. Kaitaishinsho no jidai. Edo no bunka no hon'yaku wo saguru [Wiek Kaitaishinsho. W poszukiwaniu tłumaczenia kultury Edo]. Tōkyō: Waseda Daigaku Shuppanbu, 1987.

Tamura, Yoshirō (red.). Nihon ni okeru sei to shi no shisō [Ideologia życia i śmierci w Japonii]. Tōkyō: Yūhikaku, 1983.

Tubielewicz, Jolanta. Kultura Japonii. Stownik. Warszawa: Wydawnictwo Szkolne i Pedagogiczne, 1996.

Tubielewicz, Jolanta. 2011. „Superstitions, Magic and Mantic Practices in the Heian Period - Part One". Analecta Nipponica 1/2. Red. A.F. Majewicz. Warszawa: Polish Association for Japanese Studies, 2001. S. 139-202.

Wilson, Jean (red.). Lafcadio Hearn: Japan's Great Interpreter: a New Anthology of His Writings, 1894-1904. Kent: Psychology Press, 1992.

Yokoyama, Yasuko. Edo Tōkyō no kaidan bunka no seiritsu to hensen [Powstanie i przemiana kultury kaidan Edo-Tokio]. Tōkyō: Kazamashobō, 1997. 